\title{
Detection of atmospheric gaseous amines and amides by a high-resolution time-of-flight chemical ionization mass spectrometer with protonated ethanol reagent ions
}

\author{
Lei Yao ${ }^{1}$, Ming-Yi Wang ${ }^{1, a}$, Xin-Ke Wang ${ }^{1}$, Yi-Jun Liu ${ }^{1, b}$, Hang-Fei Chen ${ }^{1}$, Jun Zheng ${ }^{2}$, Wei Nie ${ }^{3,4}$, Ai-Jun Ding ${ }^{3,4}$, \\ Fu-Hai Geng ${ }^{5}$, Dong-Fang Wang ${ }^{6}$, Jian-Min Chen ${ }^{1}$, Douglas R. Worsnop ${ }^{7}$, and Lin Wang ${ }^{1,4}$ \\ ${ }^{1}$ Shanghai Key Laboratory of Atmospheric Particle Pollution and Prevention (LAP ${ }^{3}$ ), Department of Environmental \\ Science \& Engineering, Fudan University, Shanghai 200433, China \\ ${ }^{2}$ Jiangsu Key Laboratory of Atmospheric Environment Monitoring and Pollution Control, Nanjing University \\ of Information Science \& Technology, Nanjing 210044, China \\ ${ }^{3}$ Joint International Research Laboratory of Atmospheric and Earth System Sciences, School of Atmospheric \\ Science, Nanjing University, Nanjing 210023, China \\ ${ }^{4}$ Collaborative Innovation Center of Climate Change, Nanjing 210023, China \\ ${ }^{5}$ Shanghai Meteorology Bureau, Shanghai 200135, China \\ ${ }^{6}$ Shanghai Environmental Monitoring Center, Shanghai 200030, China \\ ${ }^{7}$ Aerodyne Research, Billerica, MA 01821, USA \\ ${ }^{a}$ now at: Center for Atmospheric Particle Studies, Carnegie Mellon University, Pittsburgh, PA 15213, USA \\ ${ }^{b}$ now at: Pratt School of Engineering, Duke University, Durham, NC 27705, USA
}

Correspondence to: Lin Wang(lin_wang@fudan.edu.cn)

Received: 7 June 2016 - Published in Atmos. Chem. Phys. Discuss.: 22 June 2016

Revised: 15 October 2016 - Accepted: 3 November 2016 - Published: 23 November 2016

\begin{abstract}
Amines and amides are important atmospheric organic-nitrogen compounds but high time resolution, highly sensitive, and simultaneous ambient measurements of these species are rather sparse. Here, we present the development of a high-resolution time-of-flight chemical ionization mass spectrometer (HR-ToF-CIMS) method, utilizing protonated ethanol as reagent ions to simultaneously detect atmospheric gaseous amines $\left(C_{1}\right.$ to $\left.C_{6}\right)$ and amides $\left(C_{1}\right.$ to $\left.C_{6}\right)$. This method possesses sensitivities of $5.6-19.4 \mathrm{~Hz} \mathrm{pptv}^{-1}$ for amines and $3.8-38.0 \mathrm{~Hz} \mathrm{pptv}^{-1}$ for amides under total reagent ion signals of $\sim 0.32 \mathrm{MHz}$. Meanwhile, the detection limits were $0.10-0.50 \mathrm{pptv}$ for amines and 0.29-1.95 pptv for amides at $3 \sigma$ of the background signal for a 1 min integration time. Controlled characterization in the laboratory indicates that relative humidity has significant influences on the detection of amines and amides, whereas the presence of organics has no obvious effects. Ambient measurements of amines and amides utilizing this method were conducted from 25 July to 25 August 2015 in urban Shanghai, China. While the
\end{abstract}

concentrations of amines ranged from a few parts per trillion by volume to hundreds of parts per trillion by volume, concentrations of amides varied from tens of parts per trillion by volume to a few parts per billion by volume. Among the $\mathrm{C}_{1}$ to $\mathrm{C}_{6}$-amines, the $\mathrm{C}_{2}$-amines were the dominant species with concentrations up to $130 \mathrm{pptv}$. For amides, the $\mathrm{C}_{3}$-amides (up to $8.7 \mathrm{ppb}$ ) were the most abundant species. The diurnal and backward trajectory analysis profiles of amides suggest that in addition to the secondary formation of amides in the atmosphere, industrial emissions could be important sources of amides in urban Shanghai. During the campaign, photooxidation of amines and amides might be a main loss pathway for them in daytime, and wet deposition was also an important sink. 


\section{Introduction}

Amines and amides are nitrogen-containing organic compounds widely observed in the atmosphere (Cape et al., 2011; Cheng et al., 2006; Ge et al., 2011; Laskin et al., 2009; Rogge et al., 1991;). They are emitted from a variety of natural and anthropogenic sources including agriculture, biomass burning, animal husbandry, cooking, smoking, synthetic leather, carbon capture, and other industrial processes (FinlaysonPitts and Pitts, 2000; Ge et al., 2011; Kim et al., 2004; Kuhn et al., 2011; Nielsen et al., 2012; Schmeltz and Hoffmann, 1977; Zhu et al., 2013). In addition to the primary sources, amides can be formed from the degradation processes of amines (Nielsen et al., 2012) and atmospheric accretion reactions of organic acids with amines or ammonia (Barsanti and Pankow, 2006).

Once in the atmosphere, amines and amides can react with atmospheric oxidants (e.g., $\mathrm{OH}$ and $\mathrm{NO}_{3}$ radicals, $\mathrm{Cl}$ atoms, and $\mathrm{O}_{3}$ ), and lead to gaseous degradation products and the formation of secondary organic aerosols (Barnes et al., 2010; Bunkan et al., 2016; El Dib and Chakir, 2007; Lee and Wexler, 2013; Malloy et al., 2009; Murphy et al., 2007; Nielsen et al., 2012). In addition, the basic nature of amines certainly justifies their participation in atmospheric new particle formation and growth events (Almeida et al., 2013; Berndt et al., 2010; Erupe et al., 2011; Glasoe et al., 2015; Kurtén et al., 2008; Murphy et al., 2007; Smith et al., 2010; Yu et al., 2012; Zhang et al., 2012). Compared with amines, acetamide (AA) has a very weak positive enhancement on the nucleation capability of sulfuric acid (Glasoe et al., 2015). Heterogeneous uptake of amines by acidic aerosols and displacement reactions of ammonium ions by amines can significantly alter the physicochemical properties of aerosol particles (Bzdek et al., 2010; Kupiainen et al., 2012; Qiu et al., 2011; Wang et al., 2010a, b).

Atmospheric gaseous amines have been measured in different surroundings. Kieloaho et al. (2013) used offline acidimpregnated fiberglass filter collection together with analysis by a high-performance liquid chromatography electrospray ionization ion trap mass spectrometer, and reported that the highest concentrations of $\mathrm{C}_{2}$-amines (ethylamine (EA) + dimethylamine (DMA)) and the sum of propylamine and trimethylamine (TMA) reached $157 \pm 20$ pptv (parts per trillion by volume) and $102 \pm 61 \mathrm{pptv}$, respectively, in boreal forests in southern Finland. Using a similar detection method, the mean concentrations of $\mathrm{C}_{2}$-amines (EA+DMA), $\mathrm{C}_{3}$-amines (propylamine+TMA), butylamine (BA), diethylamine (DEA) and TMA were measured to be 23.6, 8.4, 0.3, 0.3 , and 0.1 pptv, respectively, in urban air of Helsinki, Finland (Hellén et al., 2014). Detection of gaseous alkyl amines were conducted in Toronto, Canada, using an ambient ion monitor ion chromatography system, and the concentrations of DMA, and TMA+DEA were both less than $2.7 \mathrm{pptv}$ (parts per trillion by volume; VandenBoer et al. 2011). In addition, Dawson et al. (2014) reported that TMA concentration was up to $6.8 \mathrm{ppbv}$ (parts per billion by volume) in Chino, USA, using an offline ion chromatography analysis method.

Recently, online detection of atmospheric amines using a chemical ionization mass spectrometer has become the trend. Yu and Lee (2012) utilized a quadrupole chemical ionization mass spectrometer (CIMS) with protonated ethanol and acetone ions as reagent ions to measure $\mathrm{C}_{2}$-amines $(8 \pm 3 \mathrm{pptv})$ and $\mathrm{C}_{3}$-amines ( $16 \pm 7 \mathrm{pptv}$ ) in Kent, Ohio. A similar method detected from a few parts per trillion by volume to tens of parts per trillion by volume of $\mathrm{C}_{3}$-amines in Alabama forest (You et al., 2014). Sellegri et al. (2005) reported the mean concentration of TMA and DMA were 59 and $12.2 \mathrm{pptv}$, respectively, in Hyytiälä forest, with a quadrupole-CIMS with hydronium ions as reagent ions. Additionally, at the same site, DMA concentration was measured to be less than 150 ppqv (parts per quadrillion by volume) in May-June 2013 by an atmospheric pressure CIMS based on bisulfatecluster method for DMA detection (Sipilä et al. 2015). Measurements of amines in urban areas did not show significant differences in terms of the absolute concentration. The average of total amines $\left(\mathrm{C}_{1}-\mathrm{C}_{3}\right)$ was $7.2 \pm 7.4 \mathrm{pptv}$ in Nanjing, China, as measured by a high-resolution time-of-flight CIMS (HR-ToF-CIMS) with hydronium ions as reagent ions (Zheng et al., 2015). Measurements by an ambient pressure proton transfer mass spectrometer (AmPMS) in urban Atlanta showed that TMA (or isomers or amide) was the most abundant amine species and that the concentration of DMA was $\sim 3$ pptv (Hanson et al., 2011).

To the best of our knowledge, gaseous amides were not previously measured in ambient air, except for two studies that briefly described the detection of a few amides near the emission source. Zhu et al. (2013) detected formamide (FA; $\mathrm{C}_{1}$-amide) formed from degradation of mono-ethanolamine in emissions from an industrial carbon capture facility, using proton transfer reaction time-of-flight mass spectrometry (PTR-ToF-MS). Furthermore, up to 4350 pptv of dimethylamide was observed near a municipal incinerator, waste collection center, and sewage treatment plant (Leach et al., 1999).

Given the important role of amines in atmospheric nucleation and other physicochemical processes, and the potential involvement of amides in a number of atmospheric processes, it is necessary to develop high time resolution and highly sensitive detection techniques for measurements of ambient amines and amides. Previous studies have proven CIMS to be a powerful instrument to detect gaseous amines and amides in laboratory studies and field campaigns (Borduas et al., 2015; Bunkan et al., 2016; Hanson et al., 2011; Sellegri et al., 2005; Simon et al., 2016; Sipilä et al., 2015; Yu and Lee, 2012; You et al., 2014; Zheng et al., 2015). However, the detection method for ambient amides with much lower concentrations than those in laboratory studies is still lacking. The popular usage of hydronium ions as reagent ions (e.g., PTR-MS and AmPMS) potentially leads to the relative humidity $(\mathrm{RH})$ dependence of the background and 
Table 1. Proton affinity, sensitivity, calibration coefficient, 1 min detection limit at $3 \sigma$ of background signal during the laboratory characterization, and ambient background of selected amines and amides.

\begin{tabular}{|c|c|c|c|c|c|}
\hline Compounds & $\begin{array}{r}\text { Proton affinity } \\
\left(\mathrm{kcal} \mathrm{mol}^{-1}\right) \\
(\mathrm{NIST}, 2016)\end{array}$ & $\begin{array}{r}\text { Sensitivity } \\
(\text { mean } \pm \sigma) \\
\left(\mathrm{Hz} \mathrm{pptv}^{-1}\right)^{\mathrm{a}}\end{array}$ & $\begin{array}{r}\text { Calibration } \\
\text { coefficient } \\
\left(10^{-2} \mathrm{MHz}\right. \\
\left.\mathrm{Hz}^{-1} \mathrm{pptv}\right)\end{array}$ & $\begin{array}{r}\text { Detection } \\
\text { limit } \\
(\mathrm{pptv})\end{array}$ & $\begin{array}{r}\text { Ambient } \\
\text { background } \\
(\text { mean } \pm \sigma) \\
(\text { pptv })^{b}\end{array}$ \\
\hline Water & 165.2 & & & & \\
\hline Ethanol & 185.6 & & & & \\
\hline Ammonia & 204.0 & & & & \\
\hline Trimethylamine (an isomer of $\mathrm{C}_{3}$-amines) & 226.8 & $19.4 \pm 1.3$ & 1.70 & 0.10 & $0.41 \pm 0.14$ \\
\hline Diethylamine (an isomer of $\mathrm{C}_{4}$-amines) & 227.6 & $6.4 \pm 0.4$ & 5.03 & 0.42 & $3.59 \pm 1.04$ \\
\hline$N, N$-Dimethyl-2-propanamine (an isomer of $\mathrm{C}_{5}$-amines) & 232.0 & & & & $0.68 \pm 0.32$ \\
\hline Triethylamine (an isomer of $\mathrm{C}_{6}$-amines) & 234.7 & & & & $1.76 \pm 0.79$ \\
\hline Formamide $\left(\mathrm{C}_{1}\right.$-amide $)$ & 196.5 & $38.0 \pm 1.2$ & 0.78 & 0.29 & $0.59 \pm 0.50$ \\
\hline$N, N$-Dimethylformamide (an isomer of $\mathrm{C}_{3}$-amides) & 212.1 & & & & \\
\hline$N$-Ethylacetamide (an isomer of $\mathrm{C}_{4}$-amides) & 214.6 & & & & $13.59 \pm 10.01$ \\
\hline$N, N$-Dimethylacetamide (an isomer of $\mathrm{C}_{4}$-amides) & 217.0 & & & & \\
\hline 2,2-Dimethyl-propanamide (an isomer of $\mathrm{C}_{5}$-amides) & 212.5 & & & & $8.47 \pm 5.18$ \\
\hline$N, N$-Dimethylbutyramide (an isomer of $\mathrm{C}_{6}$-amides) & 220.3 & & & & $2.60 \pm 1.40$ \\
\hline
\end{tabular}

${ }^{\text {a }}$ Sensitivities were obtained under total reagent ion signals of $\sim 0.32 \mathrm{MHz}$. ${ }^{\mathrm{b}}$ Mean background values throughout the entire campaign \pm 1 standard deviation for $\mathrm{C}_{1}$ - to $\mathrm{C}_{6}$-amines and $\mathrm{C}_{1}$ - to $\mathrm{C}_{6}$-amides.

ambient amine signals, adding uncertainties to measurement results (Hanson et al., 2011; Zheng et al., 2015; Zhu et al., 2013). In addition, constrained by the mass resolution of the quadrupole-detector mass spectrometer, it is difficult to distinguish protonated amines and amides with an identical unit mass, which pre-excludes the possibility of simultaneous measurements of amines and amides. For example, the $m / z$ (mass to charge ratio) value of protonated trimethylamine $\left(\mathrm{C}_{3} \mathrm{H}_{9} \mathrm{~N} \cdot \mathrm{H}^{+}, m / z 60.0808\right)$ and that of protonated acetamide $\left(\mathrm{C}_{2} \mathrm{H}_{5} \mathrm{NO} \cdot \mathrm{H}^{+}, m / z 60.0444\right)$ are very close.

In the present study, a HR-ToF-CIMS method utilizing protonated ethanol as reagent ions has been developed to simultaneously detect atmospheric gaseous amines $\left(\mathrm{C}_{1}\right.$ to $\left.\mathrm{C}_{6}\right)$ and amides $\left(\mathrm{C}_{1}\right.$ to $\left.\mathrm{C}_{6}\right)$. The proton affinity of ethanol $\left(185.6 \mathrm{kcal} \mathrm{mol}^{-1}\right)$ is higher than that of water ( $\left.165.2 \mathrm{kcal} \mathrm{mol}^{-1}\right)$, as shown in Table 1 , resulting in more selectivity for detecting high proton affinity species (e.g., $>196 \mathrm{kcal} \mathrm{mol}^{-1}$ for amines and amides; Nowak et al., 2002; Yu and Lee, 2012; You et al., 2014). The influences of RH and organics on amine and amide detection were characterized in the laboratory. Ambient measurements of amines and amides utilizing this method were performed from 25 July to 25 August 2015 in urban Shanghai, China. During the campaign, a filter inlet for gases and aerosols (FIGAERO) was interfaced to HR-ToF-CIMS (Lopez-Hilfiker et al., 2014), but only results on gaseous $\mathrm{C}_{1}-\mathrm{C}_{6}$ amines and amides are pre- sented. The potential sources and sinks of amines and amides are discussed.

\section{Experiment}

\subsection{Instrumentation}

An aerodyne HR-ToF-CIMS (Bertram et al., 2011) with protonated ethanol as reagent ions has been deployed to detect gaseous amines $\left(C_{1}\right.$ to $\left.C_{6}\right)$ and amides $\left(C_{1}\right.$ to $\left.C_{6}\right)$. Protonated ethanol reagent ions were generated by passing a pure air flow of $1 \mathrm{~L} \mathrm{~min}^{-1}$ supplied by a zero air generator (Aadco 737) through a Pyrex bubbler containing ethanol ( $\geq 96 \%$, J.T. Baker) and then through a $0.1 \mathrm{mCi}^{241} \mathrm{Am}$ radioactive source. A sample flow of $1.35 \mathrm{~L} \mathrm{~min}^{-1}$ was introduced into the ion-molecule reaction (IMR) chamber where the sample flow and the reagent ion flow converge. The pressures of the IMR chamber and the small-segmented quadrupole (SSQ) were regulated at $\sim 100$ and $\sim 2.8$ mbar, respectively, to increase the instrument sensitivity. Under such conditions, the ion-molecule reaction time was $\sim 320 \mathrm{~ms}$ in the IMR. To minimize wall loss of analytes on the inner surface of IMR, the temperature of IMR was maintained at an elevated temperature $\left(50^{\circ} \mathrm{C}\right)$. The data of HR-ToF-CIMS were collected at $1 \mathrm{~Hz}$ time resolution. 
Under dry conditions, the most abundant reagent ion was the protonated ethanol dimer $\left(\left(\mathrm{C}_{2} \mathrm{H}_{5} \mathrm{OH}\right)_{2} \cdot \mathrm{H}^{+}\right.$, $\mathrm{m} / \mathrm{z}$ 93.0910), with the second most dominant ions being the protonated ethanol monomer $\left(\left(\mathrm{C}_{2} \mathrm{H}_{5} \mathrm{OH}\right) \cdot \mathrm{H}^{+}\right.$, $m / z 47.0491)$ and the protonated ethanol trimer $\left(\left(\mathrm{C}_{2} \mathrm{H}_{5} \mathrm{OH}\right)_{3} \cdot \mathrm{H}^{+}, m / z 139.1329\right)$. The presence of water led to the formation of clusters of protonated ethanol with water $\left(\mathrm{C}_{2} \mathrm{H}_{5} \mathrm{OH} \cdot \mathrm{H}_{2} \mathrm{O} \cdot \mathrm{H}^{+}\right)$and hydronium ions and their hydrates $\left(\left(\mathrm{H}_{2} \mathrm{O}\right)_{n} \cdot \mathrm{H}^{+}, n=1,2\right.$, and 3). A typical mass spectrum under $<20 \% \mathrm{RH}$ is shown in Fig. S1 in the Supplement. The ratio of the oxygen cation $\left(\mathrm{O}_{2}^{+}\right)$to the total reagent ions (the sum of $\left(\mathrm{C}_{2} \mathrm{H}_{5} \mathrm{OH}\right) \cdot \mathrm{H}^{+},\left(\mathrm{C}_{2} \mathrm{H}_{5} \mathrm{OH}\right)_{2} \cdot \mathrm{H}^{+}$, and $\left.\left(\mathrm{C}_{2} \mathrm{H}_{5} \mathrm{OH}\right)_{3} \cdot \mathrm{H}^{+}\right)$was $\sim 0.001$. For the clusters of protonated ethanol with water $\left(\mathrm{C}_{2} \mathrm{H}_{5} \mathrm{OH} \cdot \mathrm{H}_{2} \mathrm{O} \cdot \mathrm{H}^{+}\right)$, the ratio was $\sim 0.026$. Additionally, the ratio of hydronium ions $\left(\left(\mathrm{H}_{2} \mathrm{O}\right)_{n} \cdot \mathrm{H}^{+}, n=1,2\right.$, and 3$)$ to the total reagent ion was $\sim 0.011$.

Amines and amides reacted dominantly with protonated ethanol ions $\left(\left(\mathrm{C}_{2} \mathrm{H}_{5} \mathrm{OH}\right)_{n} \cdot \mathrm{H}^{+}, n=1,2\right.$, and 3), compared to water clusters, with the formation of protonated amines and amides clustering with up to one molecule of ethanol. The ion-molecule reactions of amines (denoted as $\mathrm{NR}_{3}$, with $R$ being either a hydrogen atom or an alkyl group) and amides (denoted as $R_{2}^{\prime} \mathrm{NC}(\mathrm{O}) \mathrm{R}$, with $R^{\prime}$ being either a hydrogen atom or an alkyl group) with protonated ethanol reagent ions can be represented by the following reactions (You et al., 2014; Yu and Lee, 2012):

$$
\begin{aligned}
& \left(\mathrm{C}_{2} \mathrm{H}_{5} \mathrm{OH}\right)_{n} \cdot \mathrm{H}^{+}+\mathrm{NR}_{3} \rightarrow\left(\mathrm{C}_{2} \mathrm{H}_{5} \mathrm{OH}\right)_{j} \cdot \mathrm{NR}_{3} \cdot \mathrm{H}^{+} \\
& +(n-j) \mathrm{C}_{2} \mathrm{H}_{5} \mathrm{OH} \\
& \left(\mathrm{C}_{2} \mathrm{H}_{5} \mathrm{OH}\right)_{n} \cdot \mathrm{H}^{+}+R_{2}^{\prime} \mathrm{NC}(\mathrm{O}) R \rightarrow\left(\mathrm{C}_{2} \mathrm{H}_{5} \mathrm{OH}\right)_{j} \\
& \cdot R_{2}^{\prime} \mathrm{NC}(\mathrm{O}) R \cdot \mathrm{H}^{+}+(n-j) \mathrm{C}_{2} \mathrm{H}_{5} \mathrm{OH},
\end{aligned}
$$

where $n=1,2$, and 3 , and $j=0$ and 1 .

\subsection{Calibration of amines and amides}

Amines and amides were calibrated using permeation sources. Permeation tubes for amines (methylamine (MA), DMA, TMA, and DEA) were purchased from VICI Inc. USA, whereas those for amides (FA, $\geq 99.5 \%$, GC, Sigma Aldrich; AA, $\geq 99 \%$, GC, Sigma Aldrich; and propanamide (PA), $\geq 96.5 \%$, GC, Sigma Aldrich) were made in-house using $1 / 4$ in. Teflon tubes with the ends sealed with Teflon blockers. The permeation tube was placed in a U-shaped glass tube with a diameter of $2.5 \mathrm{~cm}$ that was immersed in a liquid bath with precise temperature regulation (Zheng et al., 2015). A high-purity ( $\geq 99.999 \%$ ) nitrogen flow typically at $0.1 \mathrm{~L} \mathrm{~min}^{-1}$ was used as the carrier gas to carry the permeated compounds to HR-ToF-CIMS for detection.

The concentration of an amine in the outflow of the permeation tube was determined by an acid-base titration method (Freshour et al., 2014). The high-purity nitrogen flow containing an amine standard was bubbled through a $\mathrm{HCl}$ solution $(\mathrm{pH}=\sim 4.5)$ with a small amount of $\mathrm{KCl}(\sim 5 \mathrm{mM})$ added to facilitate measurements of $\mathrm{pH}$ values. Reagents $\mathrm{HCl}(\sim 37 \mathrm{wt} \%$ in water) and $\mathrm{KCl}(\geq 99 \%)$ were of ACS reagents and purchased from Sigma Aldrich. The concentration of the amine was derived according to variations of the $\mathrm{pH}$ values with titration time. The $\mathrm{pH}$ values were averaged and recorded by a $\mathrm{pH}$ meter (340i, WTW, Germany) every 5 min.

In the case of amides, a permeated alkyl amide was trapped in $\mathrm{HNO}_{3}$ solution with a $\mathrm{pH}$ of $\sim 2.5$ that was diluted from reagent $\mathrm{HNO}_{3}(\sim 70 \mathrm{wt} \%$ in water, ACS reagent, Sigma Aldrich). Hydrolysis of the alkyl amide occurred under acidic conditions leading to formation of $\mathrm{NH}_{4}^{+}$(Cox and Yates, 1981). The concentration of $\mathrm{NH}_{4}^{+}$was quantified using ion chromatography (Metrohm 833, Switzerland), and the permeation rate of the alkyl amide was derived from the variation of $\mathrm{NH}_{4}^{+}$with the time period of hydrolysis.

The total ethanol reagent ion signals, i.e., the sum of the protonated ethanol monomer, dimer, and trimer, during the laboratory calibration were typically $\sim 0.32 \mathrm{MHz}$, which yields a small correction because of the variation in total reagent ions between laboratory calibration and field measurements, as stated in Sect. 2.4.

\subsection{Influence of RH and organics}

Experiments were performed to characterize the influence of RH and organics on the detection of amines and amides. The schematics of our experimental setup are shown in Fig. S2 (A for tests at elevated $\mathrm{RH}$ and B for tests in presence of organics), where the tubes and valves are made of polytetrafluoroethylene (PTFE) and perfluoroalkoxy (PFA) materials to minimize absorption of amines or amides on the inner surface of tubes and valves. To examine the influence of $\mathrm{RH}$, a pure air flow was directed through a bubbler filled with $18.2 \mathrm{M} \Omega \mathrm{cm}$ deionized water, and then mixed with the amine or amide flow of $0.1 \mathrm{~L} \mathrm{~min}^{-1}$ generated from the permeation sources. The examined RH ranged from 4 to $65 \%$.

$\alpha$-Pinene, a typical biogenic organic compound, and $p$ xylene, a typical anthropogenic compound, were chosen to examine the influence of organics on detection of amines and amides. The amines or amide flow was mixed with organics for $\sim 0.2 \mathrm{~s}$ before entering the IMR. During the characterization, the air flow (15 $\left.\mathrm{L} \mathrm{min}^{-1}\right)$ containing $\alpha$-pinene or $p$-xylene with concentrations up to $\sim 200$ ppbv was initially mixed with the amine or amide flow of $0.1 \mathrm{~L} \mathrm{~min}^{-1}$ generated from the permeation sources. Then ozone and $\mathrm{OH}$ radicals were generated from an $\mathrm{O}_{2} / \mathrm{H}_{2} \mathrm{O}$ flow of $2 \times 10^{-3} \mathrm{~L} \mathrm{~min}^{-1}$ by turning on a $\mathrm{Hg}$ lamp (Jelight model 600, USA). Photochemical reactions of $\alpha$-pinene or $p$-xylene occurred and a much more complex mixture of organics was subsequently mixed with the amine or amide flow. 


\subsection{Field campaign in urban Shanghai}

The ethanol HR-ToF-CIMS was deployed for a field campaign at the Fudan site $\left(31^{\circ} 17^{\prime} 54^{\prime \prime} \mathrm{N}, 121^{\circ} 30^{\prime} 05^{\prime \prime} \mathrm{E}\right)$ on the campus of Fudan University from 25 July through 25 August 2015. This monitoring site is on the rooftop of a teaching building that is $\sim 20 \mathrm{~m}$ above ground. About $100 \mathrm{~m}$ to the north is the "Middle Ring", which is one of the main overhead highways in Shanghai. This site is also influenced by local industrial and residential activities. Hence, the Fudan site is a representative urban site (Ma et al., 2014; Wang et al., 2013a, 2016; Xiao et al., 2015).

The schematic of the ethanol HR-ToF-CIMS setup during the field campaign is shown in Fig. S3. Ambient air was drawn into a PTFE tubing with a length of $2 \mathrm{~m}$ and an inner diameter of $3 / 8 \mathrm{in}$. To minimize the wall loss of amines and amides, a high sampling flow rate $\left(15 \mathrm{~L} \mathrm{~min}^{-1}\right)$ was adopted, resulting in an inlet residence time of $\sim 0.26 \mathrm{~s}$. Also, the PTFE tubing was heated to $50^{\circ} \mathrm{C}$ by heating tapes. Because of the high concentrations of volatile organic compounds in the air of urban Shanghai, reagent ion depletion occurred during the initial tests of measurements of ambient samples. Hence, the ambient air was diluted with a high-purity nitrogen flow with a dilution ratio of $\sim 1: 4.6$. Under such conditions, variation of the total reagent ions $\left(\left(\mathrm{C}_{2} \mathrm{H}_{5} \mathrm{OH}\right) \cdot \mathrm{H}^{+}\right.$, $\left(\mathrm{C}_{2} \mathrm{H}_{5} \mathrm{OH}\right)_{2} \cdot \mathrm{H}^{+}$, and $\left.\left(\mathrm{C}_{2} \mathrm{H}_{5} \mathrm{OH}\right)_{3} \cdot \mathrm{H}^{+}\right)$was less than $10 \%$ between measurements of the background air and the ambient sample. The ethanol reagent ion signals were typically around $0.35 \mathrm{MHz}$ throughout the entire campaign. To take the variation in total reagent ions between in laboratory calibration and during field measurements into account, ambient concentrations of amines and amides were calculated according to

[amines or amides $]_{\text {ambient }}=C_{\text {amines or amides }}$

$\times \frac{\sum_{n=0-1}(\text { amines or amides }) \cdot\left(\mathrm{C}_{2} \mathrm{H}_{5} \mathrm{OH}\right)_{n} \cdot \mathrm{H}^{+}}{\sum_{n=1-3}\left(\mathrm{C}_{2} \mathrm{H}_{5} \mathrm{OH}\right)_{n} \mathrm{H}^{+}}$,

where $C$ is a calibration coefficient obtained by dividing the total reagent ion signals in laboratory calibration by the sensitivity of an amine or amide. As shown in Eq. (1), to minimize the effect of the variation of reagent ions during field measurements, the ambient signals of an amine or amide were normalized by the sum of ethanol clusters including the protonated ethanol monomer, dimer, and trimer.

During the campaign, a Filter Inlet for Gases and AEROsols (FIGAERO; Lopez-Hilfiker et al., 2014) was attached to the HR-ToF-CIMS. FIGAERO-HRToF-CIMS offers two operation modes. Direct gas sample analysis occurs with the HR-ToF-CIMS during simultaneous particle collection on a PTFE filter via a separate dedicated port. Particle analysis occurs via evaporation from the filter using temperature-programmed thermal desorption by heated ultra-high-purity nitrogen upstream of the HR-ToF-CIMS. A moveable filter housing automatically switches between the
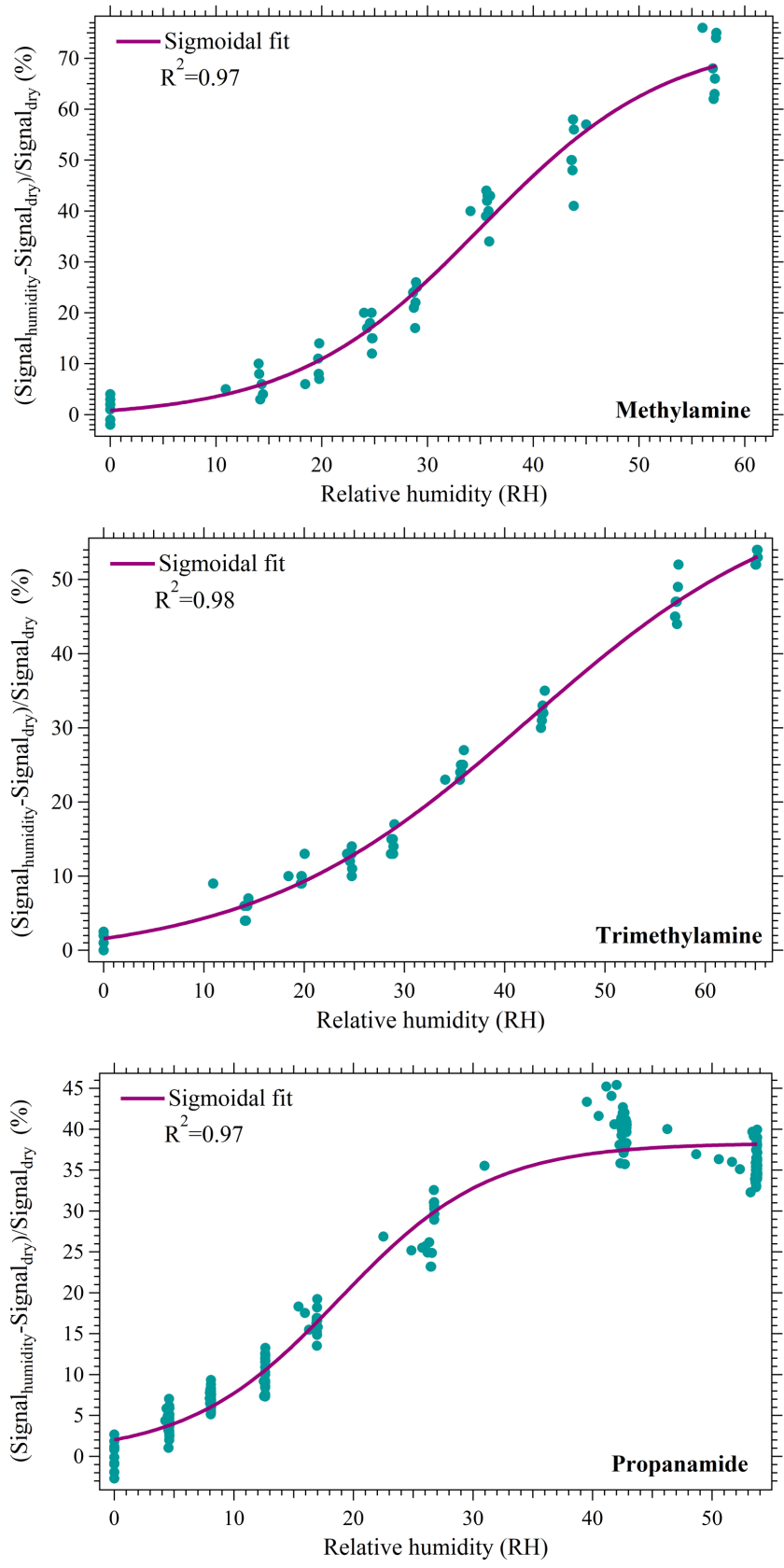

Figure 1. Influences of $\mathrm{RH}$ on the MS signals of methylamine (MA), trimethylamine (TMA), and propanamide (PA).

two modes. In our study, measurements of ambient gaseous samples were conducted for $20 \mathrm{~min}$ every hour, followed by analysis of particulate samples for $40 \mathrm{~min}$. In this paper, we focus on measurements of gaseous samples and present results on detection of gaseous amines and amides.

During the $20 \mathrm{~min}$ period for analysis of ambient gaseous samples, background measurements were auto-performed for $5 \mathrm{~min}$ by a motor-driven three-way Teflon solenoid valve, utilizing a high-purity nitrogen flow as the background gas. 
Figure $\mathrm{S} 4$ shows typical background signals during an ambient sampling period of $3 \mathrm{~h}$. The average ambient background concentrations of amines $\left(\mathrm{C}_{1}\right.$ to $\left.\mathrm{C}_{6}\right)$ and amides $\left(\mathrm{C}_{1}\right.$ to $\left.\mathrm{C}_{6}\right)$ throughout the field campaign are presented in Table 1. The inlet memory of amines and amides were determined using an inlet spike approach. As shown in Fig. S5, the signals followed the sum of two decaying exponentials. The characteristic decaying times of two exponentials, which are displacement of amines and amides inside the inlet by pumping and removing amines and amides adsorbed on the inlet surface (Zheng et al., 2015), were 1.1 and $8.5 \mathrm{~s}$ for TMA, and 1.4 and $1.4 \mathrm{~s}$ for PA, respectively. These results demonstrate that a 5 min background sampling time is sufficient to eliminate the inlet memory.

All HR-ToF-CIMS data were analyzed with Tofware (Aerodyne Research, Inc. and Tofwerk AG) and Igor Pro (Wavemetrics) software. Concentrations of $\mathrm{O}_{3}$ were measured by an $\mathrm{O}_{3}$ analyzer (Model 49i, Thermo Scientific, USA). RH and temperature were measured by an automatic meteorological station (CAWS600, Huayun, China) at the Fudan site.

Solar radiation intensity measured by a pyranometer (Kipp \& Zonen CMP6, Netherlands) was obtained from the Shanghai Pudong Environmental Monitoring Centre $\left(31^{\circ} 14^{\prime} \mathrm{N}\right.$, $121^{\circ} 32^{\prime} \mathrm{E}$, about $8.78 \mathrm{~km}$ from the Fudan site). Precipitation was recorded by a rainfall sensor (RainWise Inc., USA) located at the Huangxing Park monitoring station $\left(31^{\circ} 17^{\prime} \mathrm{N}\right.$, $121^{\circ} 32^{\prime} \mathrm{E}$, about $2.95 \mathrm{~km}$ from the Fudan site) of Shanghai Meteorology Bureau.

\section{Results and discussion}

\subsection{Performance of ethanol HR-ToF-CIMS in the laboratory}

\subsubsection{Sensitivities and detection limits}

The permeation rates of amines and amides were determined adopting methods of acid-base titration and hydrolysis of alkyl amides in an acidic solution, respectively. A typical plot for determination of the permeation rate of the DEA permeation tube is shown in Fig. S6. Plots for FA $\left(\mathrm{C}_{1}\right.$-amide) and PA (an isomer of $\mathrm{C}_{3}$-amide) are used as examples for amides, as shown in Fig. S7. In summary, at $0{ }^{\circ} \mathrm{C}$, the permeation rates of MA, DMA, TMA, and DEA permeation tubes were $6.9 \pm 0.7,7.4 \pm 0.2,5.1 \pm 0.8$, and $12.7 \pm 0.9 \mathrm{ng} \mathrm{min}^{-1}$, respectively. Permeation rates of in-house-made FA, AA, and PA permeation tubes were $36.7 \pm 2.4,5.2 \pm 0.5$, and $29.1 \pm 1.6 \mathrm{ng} \mathrm{min}^{-1}$, respectively, at $0^{\circ} \mathrm{C}$.

The high-purity nitrogen flow carrying the permeated amine or amide was then diluted with another high-purity nitrogen flow at different dilution ratios, and directed to HRToF-CIMS for detection under dry conditions $(\mathrm{RH}=\sim 0 \%)$.
Figure $\mathrm{S} 8$ shows the calibration curves of $\mathrm{C}_{1}$ - to $\mathrm{C}_{4}$-amines and $\mathrm{C}_{1}$ - to $\mathrm{C}_{3}$-amides. The derived sensitivities were 5.619.4 for amines and $3.8-38.0 \mathrm{~Hz} \mathrm{pptv}^{-1}$ for amides with the total reagent ions of $\sim 0.32 \mathrm{MHz}$, respectively. Also, the detection limits of amines and amides were $0.10-0.50$ and $0.29-1.95$ pptv, respectively, at $3 \sigma$ of the background signal for a $1 \mathrm{~min}$ integration time. Sensitivities, calibration coefficients, and detection limits of the $\mathrm{C}_{1}$ - to $\mathrm{C}_{4}$-amines (MA, DMA, TMA, and DEA) and $\mathrm{C}_{1}$ - to $\mathrm{C}_{3}$-amides (FA, AA, and $\mathrm{PA}$ ), together with their proton affinities, are summarized in Table 1 . The detection limits of $\mathrm{C}_{1}$ - to $\mathrm{C}_{3}$-amines in our study are similar to those by Zheng et al. (2015) and You et al. (2014). The sensitivities of $\mathrm{C}_{1}$ - to $\mathrm{C}_{4}$-amines are slightly better than those reported in You et al. (2014) and Yu and Lee (2012).

\subsubsection{Effects of RH and organics}

The presence of high concentrations of water is believed to have an effect on the ion-molecule reactions in IMR, given the proton transfer nature of our ion-molecule reactions and the high IMR pressure (providing longer ion-molecule reaction time) in our study. The detection of constant concentrations of amines and amides by HR-ToF-CIMS at various $\mathrm{RH}$ was characterized to evaluate the influence of RH. Examined were MA $\left(\mathrm{C}_{1}\right.$-amine $)$ and TMA $\left(\mathrm{C}_{3}\right.$-amine $)$ under $0-65 \% \mathrm{RH}$ at $23{ }^{\circ} \mathrm{C}$, corresponding to $0-70$ and $0-49 \%$ enhancement in the MS signal, respectively. In the case of amides, the increase of the PA $\left(\mathrm{C}_{3}\right.$-amide $)$ signal was $0-38$ under $0-55 \% \mathrm{RH}$. These results show that RH has an obvious effect on the MS signals for amines and amides, which followed sigmoidal fits with $R^{2} \geq 0.97$ in the examined $\mathrm{RH}$ range (Fig. 1).

At elevated $\mathrm{RH}$, high concentrations of water resulted in the production of $\left(\mathrm{H}_{2} \mathrm{O}\right)_{m} \mathrm{H}^{+}(m=1,2$ and 3) and $\mathrm{C}_{2} \mathrm{H}_{5} \mathrm{OH} \cdot \mathrm{H}_{2} \mathrm{O} \cdot \mathrm{H}^{+}$ions (Fig. S1; Nowak et al., 2002). Proton transfer reactions of $\left(\mathrm{H}_{2} \mathrm{O}\right)_{m} \mathrm{H}^{+}(m=1,2$ and 3$)$ and $\mathrm{C}_{2} \mathrm{H}_{5} \mathrm{OH} \cdot \mathrm{H}_{2} \mathrm{O} \cdot \mathrm{H}^{+}$with amines and amides might occur leading to the formation of additional protonated amines and amides. In addition, the proton affinities of amines are generally higher than those of amides. Thus, the relative enhancement was more significant for amines.

Since a large number of ambient organics can be detected by this protonated ethanol reagent ion methodology as shown later, laboratory measurements of amines and amides in presence of and in absence of organics formed from photooxidation of $\alpha$-pinene and $p$-xylene, respectively, were carried out to examine the influence of organics on detection of amines and amides. Figure 2 shows the effects of biogenic ( $\alpha$-pinene) and anthropogenic ( $p$-xylene) compounds and their photochemical reaction products on detection of amines (MA and TMA) and amide (PA) by our HR-ToFCIMS. After stable signals of amines or amide were established, introduction of $\alpha$-pinene and $p$-xylene, respectively, had little impact on detection of amines and amides. Initi- 

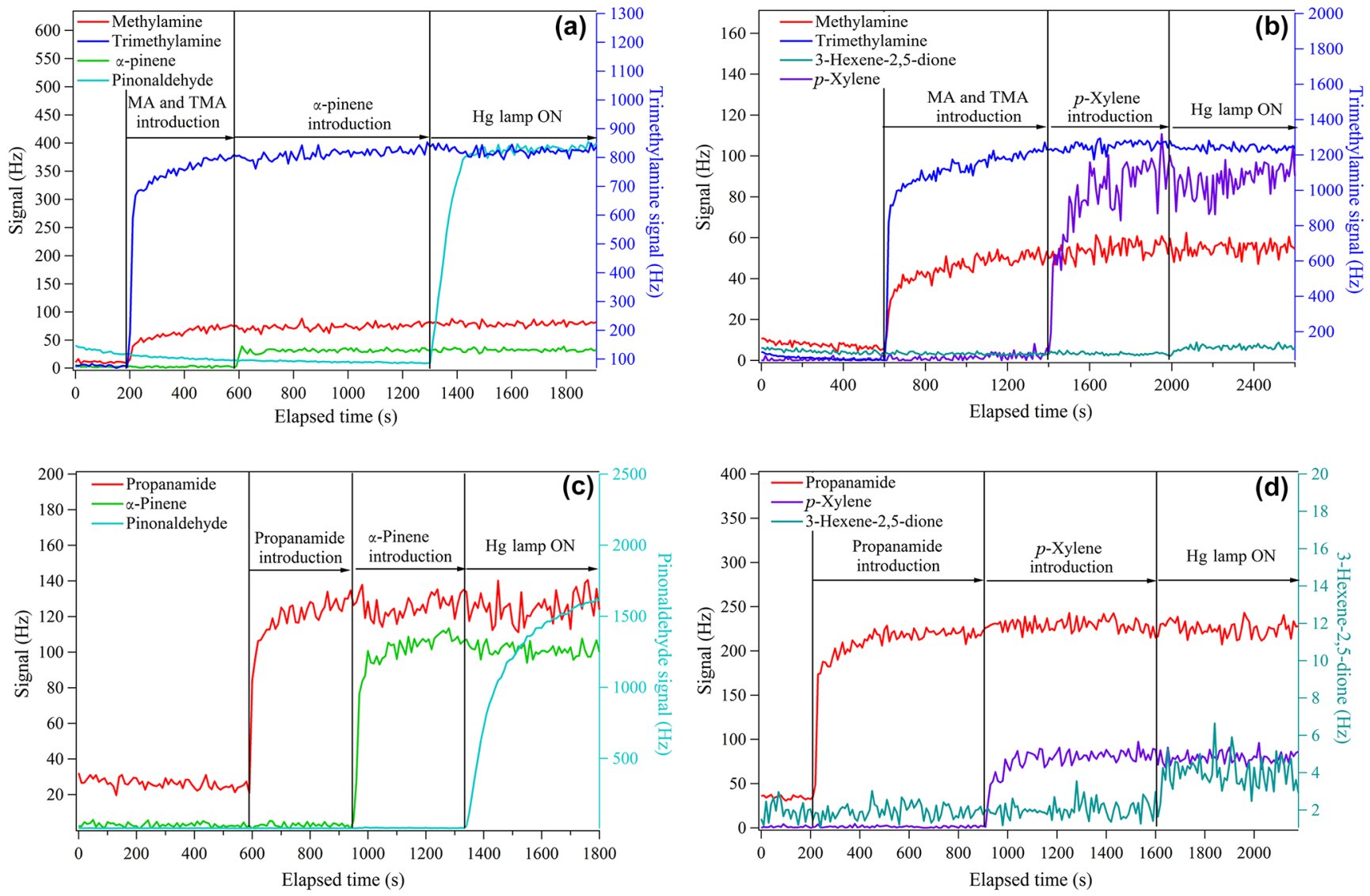

Figure 2. Influences of organics on MS signals of methylamine (MA, a and b), trimethylamine (TMA, a and b), and propanamide (PA, c and d). Note that the right axis is used for the signal with an identical color, and other signals correspond to the left axis.

ation of photochemical reactions of $\alpha$-pinene and $p$-xylene upon turning on the $\mathrm{Hg}$ lamp, as evidenced by characteristic products of pinonaldehyde from $\alpha$-pinene (Lee et al., 2006) and 3-hexene-2,5-dione from $p$-xylene (Smith et al., 1999), respectively, did not have an obvious effect on detection of amines and amides, either.

\subsection{Detection of amines and amides in urban Shanghai}

\subsubsection{Identification of nitrogen-containing species}

One major challenge during analysis of mass spectra from the field deployment of the ethanol HR-ToF-CIMS is to distinguish amines and amides with very close $m / z$ values in order to achieve simultaneous measurements. Thanks to the high mass resolving power $(R \geq 3500$ in $\mathrm{V}$-mode) of our HR-ToF-CIMS, we are able to distinguish and identify the following protonated amines: $\mathrm{CH}_{5} \mathrm{~N} \cdot \mathrm{H}^{+}$ $(m / z 32.0495), \quad \mathrm{C}_{2} \mathrm{H}_{7} \mathrm{~N} \cdot \mathrm{H}^{+}(m / z 46.0651), \quad \mathrm{C}_{3} \mathrm{H}_{9} \mathrm{~N} \cdot \mathrm{H}^{+}$ $(m / z 60.0808), \mathrm{C}_{4} \mathrm{H}_{11} \mathrm{~N} \cdot \mathrm{H}^{+}(m / z 74.0964), \mathrm{C}_{5} \mathrm{H}_{13} \mathrm{~N} \cdot \mathrm{H}^{+}$ $(m / z 88.1121)$, and $\mathrm{C}_{6} \mathrm{H}_{15} \mathrm{~N} \cdot \mathrm{H}^{+}(m / z 102.1277)$, and amides $\quad\left(\mathrm{CH}_{3} \mathrm{NO} \cdot \mathrm{H}^{+} \quad(m / z 46.0287), \quad \mathrm{C}_{2} \mathrm{H}_{5} \mathrm{NO} \cdot \mathrm{H}^{+}\right.$ $(m / z 60.0444), \mathrm{C}_{3} \mathrm{H}_{7} \mathrm{NO} \cdot \mathrm{H}^{+}(m / z 74.0600), \mathrm{C}_{4} \mathrm{H}_{9} \mathrm{NO} \cdot \mathrm{H}^{+}$ $\left(m / z\right.$ 88.0757), $\quad \mathrm{C}_{5} \mathrm{H}_{11} \mathrm{NO} \cdot \mathrm{H}^{+} \quad(m / z 102.0913), \quad$ and $\left.\mathrm{C}_{6} \mathrm{H}_{13} \mathrm{NO} \cdot \mathrm{H}^{+}(m / z 116.1069)\right)$, as well as a few oxamides $\left(\mathrm{C}_{3} \mathrm{H}_{5} \mathrm{NO}_{2} \cdot \mathrm{H}^{+}(m / z \quad 88.0393), \mathrm{C}_{4} \mathrm{H}_{7} \mathrm{NO}_{2} \cdot \mathrm{H}^{+}\right.$ $(m / z 102.0550)$, and $\left.\mathrm{C}_{5} \mathrm{H}_{7} \mathrm{NO}_{2} \cdot \mathrm{H}^{+}(m / z 116.0760)\right)$, as shown by the single peak fitting for each of them in Fig. 3. The assignment of molecular formulas for these species is within a mass tolerance of $<10 \mathrm{ppm}$, and the fitted area ranges from 99 to $101 \%$.

We further analyzed the entire mass spectra and assigned a molecular formula to 202 species with $m / z$ values less than $163 \mathrm{Th}$ as listed in Table S1 in the Supplement, which allows a mass defect plot for typical 15 min mass spectra in Fig. 4a. In addition to the protonated $\mathrm{C}_{1}$ - to $\mathrm{C}_{6}$-amines and amides, the presence of their clusters with one ethanol molecule is evident, which further confirms the identification of these species. A number of gaseous amines have been previously detected in the ambient air utilizing a quadrupole mass spectrometer (Freshour et al., 2014; Hanson et al., 2011; Sellegri et al., 2005; You et al., 2014; Yu and Lee, 2012). As suggested by Hanson et al. (2011), an amine and an amide with one fewer carbon might both have high enough proton affinities and could be detected at the same unit $m / z$ value by a quadrupole mass spectrometer, leading to uncertainty in 

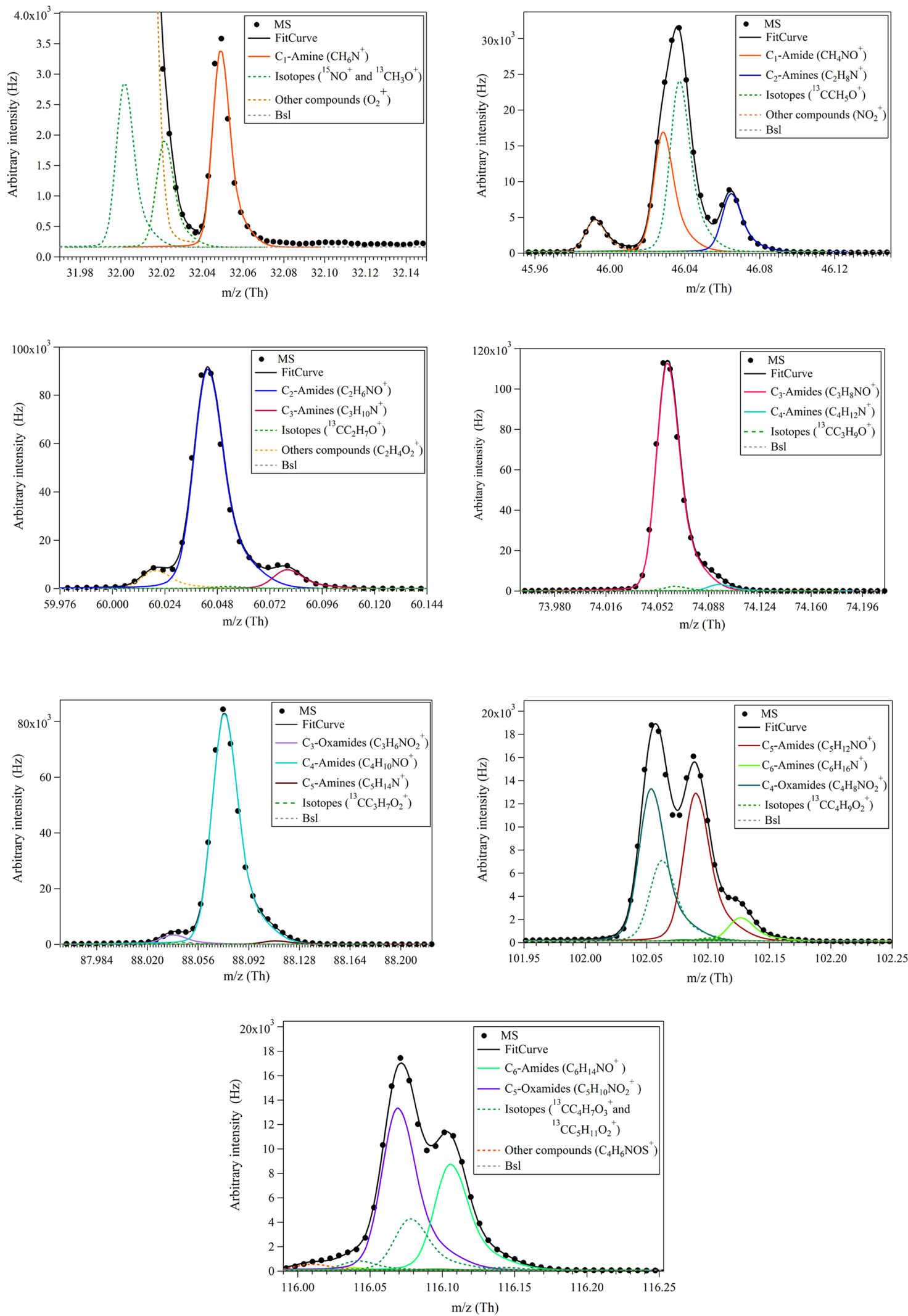

Figure 3. High-resolution single peak fitting (custom shape) for amines and amides. During the peak deconvolution, only peaks whose areas are more than $0.5 \%$ of the total will be included in the figure legend. 

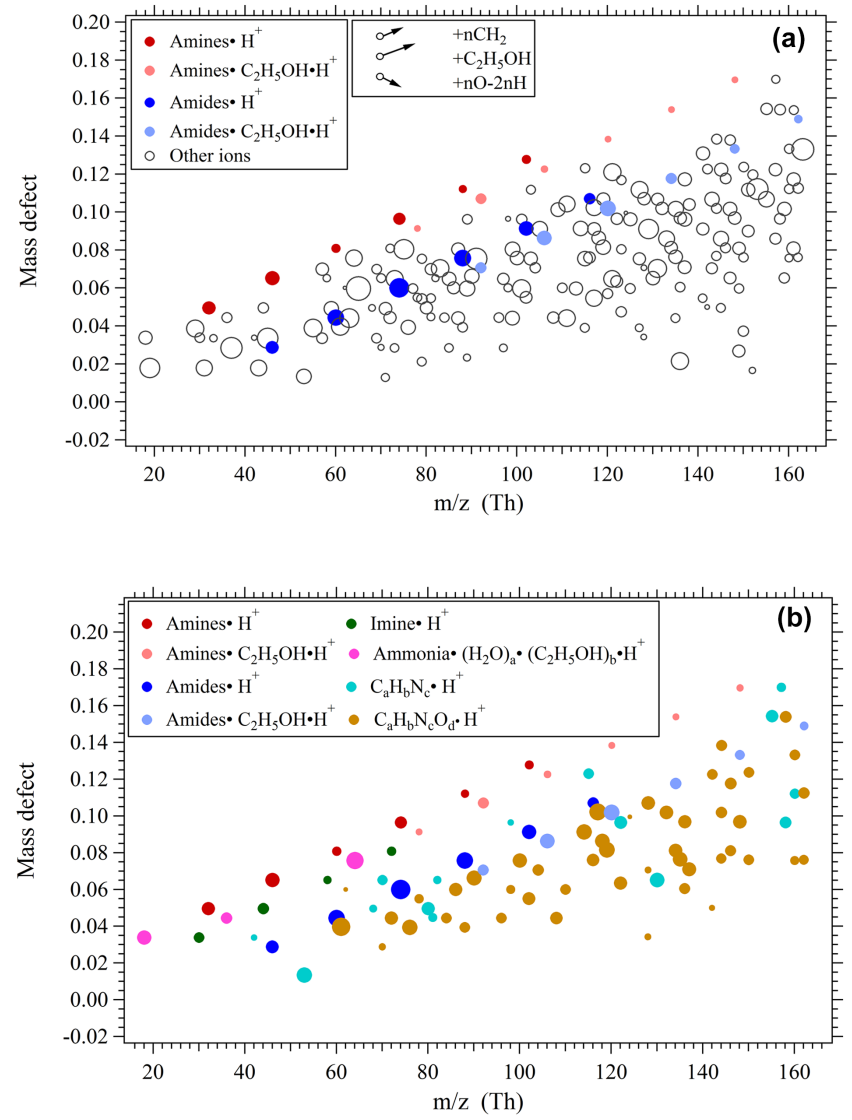

Figure 4. Mass defect diagram for (a) protonated amines $\left(\mathrm{C}_{1}-\mathrm{C}_{6}\right)$ and amides $\left(\mathrm{C}_{1}-\mathrm{C}_{6}\right)$ and their clusters with ethanol, together with other species with $m / z$ less than 163 Th in the ambient sample; and (b) all nitrogen-containing species with $\mathrm{m} / \mathrm{z}$ less than $163 \mathrm{Th}$ in the ambient sample. Circle diameters are proportional to $\log _{10}$ (count rates).

measuring the ambient amine. In this study, $\mathrm{C}_{1}$ - to $\mathrm{C}_{6}$-amines and $\mathrm{C}_{1}$ - to $\mathrm{C}_{6}$-amides are, for the first time, systematically and simultaneously detected in ambient air.

In addition to the protonated $\mathrm{C}_{1}$ - to $\mathrm{C}_{6}$-amines and $\mathrm{C}_{1}$ - to $\mathrm{C}_{6}$-amides and their clusters with ethanol, we were able to detect many other nitrogen-containing species (e.g., ammonia). Among the 202 species with $m / z$ less than $163 \mathrm{Th}$, there were 86 nitrogen-containing species (Fig. 4b and Table S1). Four imines (or enamines) including $\mathrm{CH}_{3} \mathrm{~N}, \mathrm{C}_{2} \mathrm{H}_{5} \mathrm{~N}, \mathrm{C}_{3} \mathrm{H}_{7} \mathrm{~N}$, and $\mathrm{C}_{4} \mathrm{H}_{9} \mathrm{~N}$ were detected. These imines (or enamines) could derive from photo-oxidation of amines (Nielsen et al., 2012) and play important roles in atmospheric processes (Bunkan et al., 2014). In addition, a number of heterocyclic nitrogencontaining species including pyrrole, pyrroline, pyrrolidine, pyridine, and pyrimidine were potentially detected (see Table S1). Berndt et al. (2014) reported that pyridine was able to enhance nucleation in $\mathrm{H}_{2} \mathrm{SO}_{4}-\mathrm{H}_{2} \mathrm{O}$ system. Also, proton affinities of most of these heterocyclic nitrogen-containing compounds are higher than that of ammonia; hence they po- tentially have the capacity to neutralize atmospheric acidic species (e.g., $\mathrm{H}_{2} \mathrm{SO}_{4}, \mathrm{HNO}_{3}$ and organic acids) to contribute to secondary particle formation and growth.

Apart from clusters of ammonia, $\mathrm{C}_{1}$ - to $\mathrm{C}_{6}$-amines, and $\mathrm{C}_{1}$ - to $\mathrm{C}_{6}$-amides with water or ethanol, there were $48 \mathrm{C}_{a} \mathrm{H}_{b} \mathrm{~N}_{c} \mathrm{O}_{d}$ species representing $55.8 \%$ of the total nitrogen-containing species. This suggests that more than half of the nitrogen-containing species existed as oxygenated compounds in the atmosphere in urban Shanghai. One important atmospheric nitrogen-containing compound, isocyanic acid (HNCO; Roberts et al., 2011), is not listed in Table $\mathrm{S} 1$, because the proton affinity of isocyanic acid is $180.0 \mathrm{kcal} \mathrm{mol}^{-1}$, which is less than that of ethanol $\left(185.6 \mathrm{kcal} \mathrm{mol}^{-1}\right)$. Hence, the ethanol reagent ions are not sensitive to the detection of isocyanic acid.

The remaining 116 species with $m / z$ less than $163 \mathrm{Th}$ are mostly organics (see Table S1). Above $m / z=163 \mathrm{Th}$, numerous mass peaks were observed, which are likely organics and nitrogen-containing species. These high-molecularweight species are assumed to have a low volatility and may partition between the gas phase and the particles.

\subsubsection{Time profiles of amines and amides}

During the field measurement, the average RH of the diluted gaseous samples was $15.8 \pm 3.5 \%$. According to our laboratory characterization, the MS signals of MA, TMA, and $\mathrm{PA}$ at $15.8 \% \mathrm{RH}$ have been on average enhanced by 10,9 , and $19 \%$, respectively, from our calibration under dry conditions. Here, we use our sigmoidal fits to convert each of our ambient data points to the signal under dry conditions $(\mathrm{RH}=\sim 0 \%)$, and calculate the corresponding concentration. Since MA and TMA behaved quite similarly at elevated $\mathrm{RH}$, the sigmoidal fit for TMA is also applied to the $\mathrm{C}_{2}$-amines and $\mathrm{C}_{4}$ - to $\mathrm{C}_{6}$-amines. Also, the sigmoidal fit for $\mathrm{PA}$ is adopted for other amides. Since high-purity nitrogen ( $\mathrm{RH}=\sim 0 \%$ ) was used as the background sample during the ambient campaign, no RH-dependent correction was made with background signals.

Assuming $\mathrm{C}_{1}$ - to $\mathrm{C}_{4}$-amines have the same proton affinity as MA, DMA, TMA, and DEA, respectively, the sensitivities of MA, DMA, TMA, and DEA were used to quantify $\mathrm{C}_{1}$ - to $\mathrm{C}_{4}$-amines. Since the sensitivities of $\mathrm{C}_{5}$ - to $\mathrm{C}_{6}$-amine standards were not determined, the sensitivity of DEA by HR-ToF-CIMS was adopted to quantify $\mathrm{C}_{5}$ - to $\mathrm{C}_{6}$-amines. A similar approach was utilized to quantify $C_{1}-$ to $C_{3}$-amides by sensitivities of FA, AA, and PA, respectively. In addition, the sensitivity of PA was used to quantify $\mathrm{C}_{4}$ - to $\mathrm{C}_{6}$-amides.

Figure 5 presents the time profiles for mixing ratios of $\mathrm{C}_{1}$ to $\mathrm{C}_{6}$-amines and $\mathrm{C}_{1}$ - to $\mathrm{C}_{6}$-amides from 25 July to $25 \mathrm{Au}$ gust 2015 in urban Shanghai. Note that each data point in the figure represents an average of 15 min measurements. Tables 2 and 3 summarize the mean concentrations of $\mathrm{C}_{1}$ - to $\mathrm{C}_{6}$-amines and $\mathrm{C}_{1}$ - to $\mathrm{C}_{6}$-amides throughout the entire cam- 

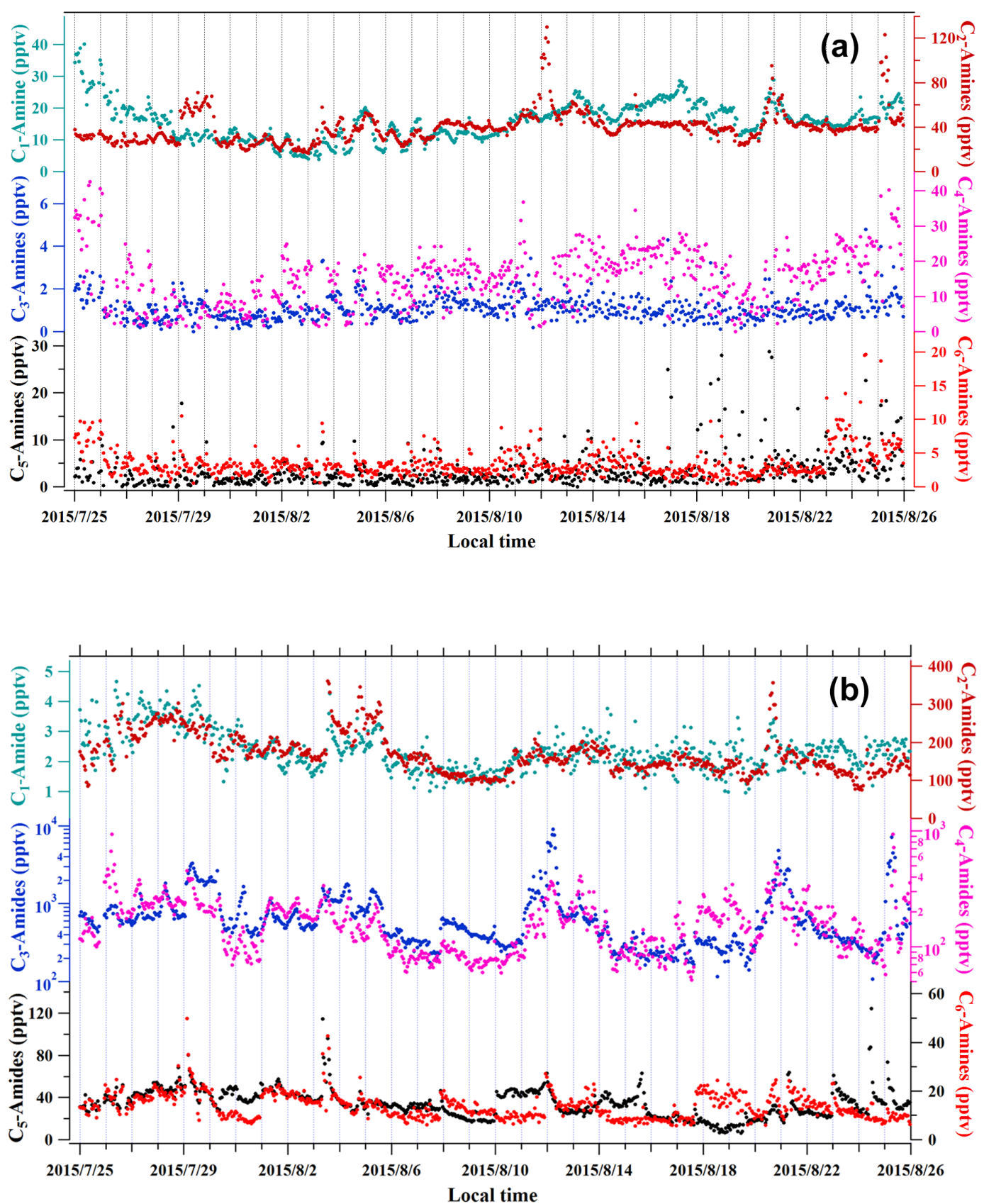

Figure 5. Time series of amines (a) and amides (b). Concentrations of amines and amides are 15 min average values.

paign, together with comparison of amine and amide concentrations reported in previous field studies.

For $\mathrm{C}_{1}$ - to $\mathrm{C}_{6}$-amines, the average concentrations $( \pm \sigma)$ were $15.7 \pm 5.9,40.0 \pm 14.3,1.1 \pm 0.6,15.4 \pm 7.9$, $3.4 \pm 3.7$, and $3.5 \pm 2.2 \mathrm{pptv}$, respectively. $\mathrm{C}_{1}$-amine, $\mathrm{C}_{2}$ amines, and $\mathrm{C}_{4}$-amines were the dominant amine species in urban Shanghai. The concentrations of amines in Shanghai are generally smaller than those in Hyytiälä, Finland (Hellén et al., 2014; Kieloaho et al., 2013; Sellegri et al., 2005) - except for in one study that, as stated by the authors, should be treated with caution (Sipilä et al. 2015) - potentially hinting that sources for amines existed in the forest region of Hyytiälä, Finland. Our $\mathrm{C}_{1}$ - and $\mathrm{C}_{2}$-amines are generally more abundant than those in agricultural, coastal, continental, suburban, and urban areas (Freshour et al., 2014; Hanson et al., 2011; Kieloaho et al., 2013; Kürten et al., 2016; Sellegri et al., 2005; You et al., 2014). However, our $\mathrm{C}_{3}$ - to $\mathrm{C}_{6}$ amines are less abundant, potentially because we are able to distinguish an amine, an amide with one fewer carbon, and an oxamide with two fewer carbons (see Fig. 3). 
Table 2. Inter-comparison of gaseous amines measured in different locations with different surroundings.

\begin{tabular}{|c|c|c|c|c|c|c|c|}
\hline $\begin{array}{l}\text { Location } \\
\text { (site type, season) }\end{array}$ & $\begin{array}{r}\mathrm{C}_{1} \text {-Amine } \\
\text { (pptv) }\end{array}$ & $\begin{array}{r}\mathrm{C}_{2} \text {-Amines } \\
(\mathrm{pptv})\end{array}$ & $\begin{array}{r}\mathrm{C}_{3} \text {-Amines } \\
(\mathrm{pptv})\end{array}$ & $\begin{array}{r}\mathrm{C}_{4} \text {-Amines } \\
\text { (pptv) }\end{array}$ & $\begin{array}{r}\mathrm{C}_{5} \text {-Amines } \\
(\mathrm{pptv})\end{array}$ & $\begin{array}{r}\mathrm{C}_{6} \text {-Amines } \\
\text { (pptv) }\end{array}$ & Ref. \\
\hline Hyytiälä, Finland (Forested, spring) & & $12.2 \pm 7.7^{\mathrm{a}}$ & $59 \pm 35.5^{\mathrm{a}}$ & & & & Sellegri et al. (2005) \\
\hline Hyytiälä, Finland (Forested, spring ) & & $<0.15$ & & & & & Sipilä et al. (2015) \\
\hline Hyytiälä, Finland (Forested, summer, and autumn) & & $157 \pm 20^{\mathrm{b}}$ & $102 \pm 61^{b}$ & $15.5 \pm 0.5^{\mathrm{b}}$ & & & Kieloaho et al. (2013) \\
\hline Hyytiälä, Finland (Forested, summer) & & $39.1^{\mathrm{c}}$ & $10.2^{\mathrm{c}}$ & $8.1^{\mathrm{c}}$ & & $1.6^{\mathrm{c}}$ & Hellén et al. (2014) \\
\hline Alabama, USA (Forested, summer) & $<1.2$ & $<4.8$ & $1-10$ & $<23.1$ & $<17.3$ & $<13.0$ & You et al. (2014) \\
\hline Vielbrunn, Germany (Agricultural, spring) & $1-5$ & $\sim 1$ & $1-5$ & $1-5$ & & $1-5$ & Kürten et al. (2016) \\
\hline Kent, USA (Suburban, winter) & $<18$ & $8 \pm 3^{\mathrm{a}}$ & $16 \pm 7^{\mathrm{a}}$ & $<41$ & & $<8$ & Yu and Lee (2012) \\
\hline Kent, USA (Suburban, summer) & $1-4$ & $<4.4$ & $5-10$ & $10-50$ & $10-100$ & $<13.1$ & You et al. (2014) \\
\hline Lewes, USA (Coastal, summer) & $5^{\mathrm{c}}$ & $28^{\mathrm{c}}$ & $6^{c}$ & $3^{c}$ & $1^{\mathrm{c}}$ & $2^{\mathrm{c}}$ & Freshour et al. (2014) \\
\hline Lamont, USA (Continental, spring) & $4^{\mathrm{c}}$ & $14^{\mathrm{c}}$ & $35^{\mathrm{c}}$ & $150^{\mathrm{c}}$ & $98^{\mathrm{c}}$ & $20^{\mathrm{c}}$ & Freshour et al. (2014) \\
\hline Nanjing, China (Industrialized, summer) & $0.1-18.9$ & $0.1-29.9$ & $0.1-9.3$ & & & & Zheng et al. (2014) \\
\hline Atlanta, USA (Urban, summer) & $<0.2$ & $0.5-2$ & $4-15$ & $\sim 5^{\mathrm{d}}$ & $4-5^{\mathrm{d}}$ & $3-25$ & Hanson et al. (2011) \\
\hline Helsinki, Finland (Urban, summer) & & $23.6^{\mathrm{c}}$ & $8.4^{\mathrm{c}}$ & $0.3^{\mathrm{c}}$ & & $0.1^{\mathrm{c}}$ & Hellén et al. (2014) \\
\hline Toronto, Canada (Urban, summer) & & $<2.7$ & & $<2.7$ & & $<1.0$ & VandenBoer et al. (2011) \\
\hline Shanghai, China (Urban, summer) & $15.7 \pm 5.9^{\mathrm{e}}$ & $40.0 \pm 14.3^{\mathrm{e}}$ & $1.1 \pm 0.6^{\mathrm{e}}$ & $15.4 \pm 7.9^{\mathrm{e}}$ & $3.4 \pm 3.7^{\mathrm{e}}$ & $3.5 \pm 2.2^{\mathrm{e}}$ & This study \\
\hline
\end{tabular}

${ }^{a}$ Mean values \pm 1 standard deviation. ${ }^{b}$ The highest concentrations during the measurement. ${ }^{c}$ Mean values. ${ }^{\mathrm{d}} 8 \mathrm{~h}$ average values. ${ }^{\mathrm{e}}$ Mean values throughout the entire campaign \pm 1 standard deviation.

Table 3. Inter-comparison of gaseous amides measured in different locations with different surroundings.

\begin{tabular}{lrrrrrrr}
\hline $\begin{array}{l}\text { Location } \\
\text { (site type, season) }\end{array}$ & $\begin{array}{r}\mathrm{C}_{1} \text {-Amide } \\
(\mathrm{pptv})\end{array}$ & $\begin{array}{r}\mathrm{C}_{2} \text {-Amides } \\
(\mathrm{pptv})\end{array}$ & $\begin{array}{r}\mathrm{C}_{3} \text {-Amides } \\
(\mathrm{pptv})\end{array}$ & $\begin{array}{r}\mathrm{C}_{4} \text {-Amides } \\
(\mathrm{pptv})\end{array}$ & $\begin{array}{r}\mathrm{C}_{5} \text {-Amides } \\
(\mathrm{pptv})\end{array}$ & $\begin{array}{r}\mathrm{C}_{6} \text {-Amides } \\
(\mathrm{pptv})\end{array}$ & $\begin{array}{r}\text { Ref. } \\
\text { (Southampton, UK (Suburban, spring, } \\
\begin{array}{l}\text { summer, and autumn) } \\
\text { Shanghai, China (Urban, summer) }\end{array}\end{array}$ \\
& $2.3 \pm 0.7^{*}$ & $169.2 \pm 51.5^{*}$ & $778.2 \pm 899.8^{*}$ & $167.8 \pm 97.0^{*}$ & $34.5 \pm 13.3^{*}$ & $13.8 \pm 5.2^{*}$ & This study \\
\hline
\end{tabular}

* Mean values throughout the entire campaign \pm 1 standard deviation.

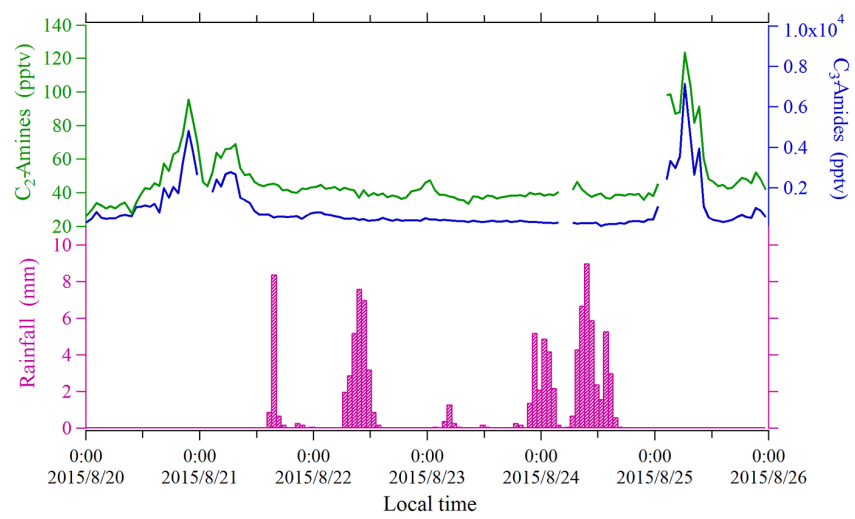

Figure 6. Time profiles of the rainfall, $\mathrm{C}_{2}$-amines, and $\mathrm{C}_{3}$-amides.

For $\mathrm{C}_{1}$ - to $\mathrm{C}_{6}$-amides, the average concentrations $( \pm \sigma)$ were $2.3 \pm 0.7,169.2 \pm 51.5,778.2 \pm 899.8,167.8 \pm 97.0$, $34.5 \pm 13.3$, and $13.8 \pm 5.2 \mathrm{pptv}$, respectively. $\mathrm{C}_{2}$-amides, $\mathrm{C}_{3}$-amides, and $\mathrm{C}_{4}$-amides were the most abundant amides in urban Shanghai during the campaign and their concentrations were up to hundreds of parts per trillion by volume. Up to now, studies that report systematic identification and quantification of amides in the ambient air are lacking. Leach et al. (1999) detected $N, N$-dimethylformamide (an isomer of $\mathrm{C}_{3}$-amides) of 368-4357 pptv in a suburban area surrounded by municipal incinerator, waste collection and processing center, and sewage treatment plant. In the ambient air, $\mathrm{C}_{1}$ - to
$\mathrm{C}_{6}$-amides may derive from oxidation of $\mathrm{C}_{1}$ - to $\mathrm{C}_{6}$-amines. $\mathrm{N}, \mathrm{N}$-dimethylformamide is a major product with a yield of $\sim 40 \%$ from photolysis experiments of TMA under high $\mathrm{NO}_{x}$ conditions (Nielsen et al, 2011). Also, the yields of formamide $\left(\mathrm{C}_{1}\right.$-amide $)$ and methylforamide $\left(\mathrm{C}_{2}\right.$-amide $)$ from $\mathrm{OH}$-initiated MA and DMA in the presence of $\mathrm{NO}_{x}$ are $\sim 11$ and $\sim 13 \%$, respectively (Nielsen et al, 2012). Comparison of the abundance of amines and amides during the campaign, together with the yields of amides from photo-oxidation of amines, suggests that the ambient $C_{1}$ - to $C_{3}$-amines were insufficient to explain the observed abundance of $\mathrm{C}_{1}$ - to $\mathrm{C}_{3}$ amides. Therefore, in addition to secondary sources, $\mathrm{C}_{1}$ - to $\mathrm{C}_{6}$-amides likely were emitted from primary sources (e.g., industrial emissions).

Figure 6 shows a close examination of the temporal variations of $\mathrm{C}_{2}$-amines and $\mathrm{C}_{3}$-amides, representatives of the observed amines and amides, together with that of rainfall between 20 and 25 August 2015. The plots clearly reveal that the concentrations of $\mathrm{C}_{2}$-amines and $\mathrm{C}_{3}$-amides on raining days were constant at low levels, much lower than those without rain, and that $\mathrm{C}_{2}$-amines and $\mathrm{C}_{3}$-amides rapidly went up after the rain. Previous studies reported that wet deposition is one of the important sinks of amines (Cornell et al., 2003; Ge et al., 2011; You et al., 2014). Our study further indicates that wet deposition (or heterogeneous reactions) is also an important sink for amides. 

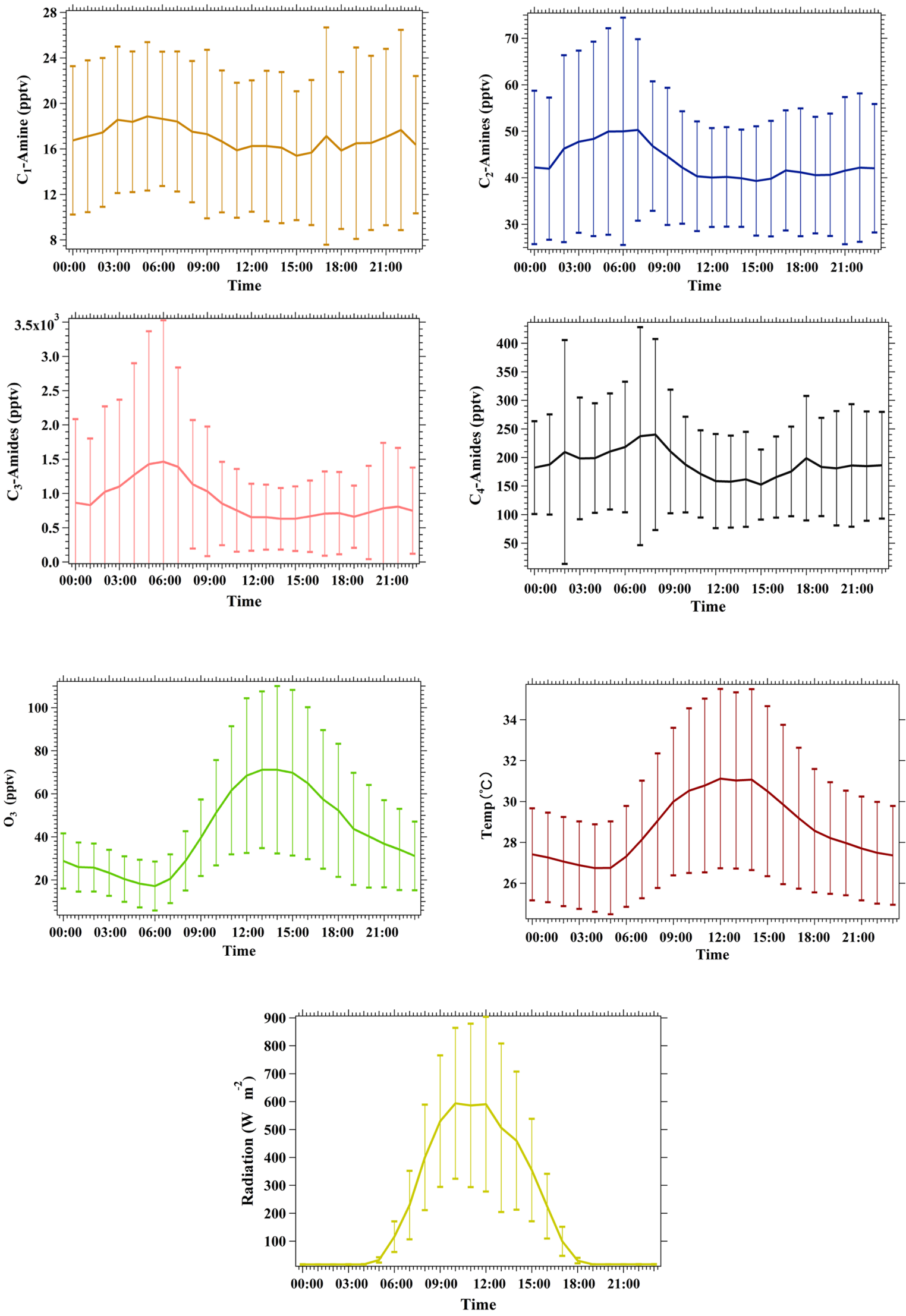

Figure 7. The averaged diurnal profiles of $\mathrm{C}_{1}$ - and $\mathrm{C}_{2}$-amines and $\mathrm{C}_{3}$ - and $\mathrm{C}_{4}$-amides, together with those of temperature, radiation, and ozone concentration during the campaign. 

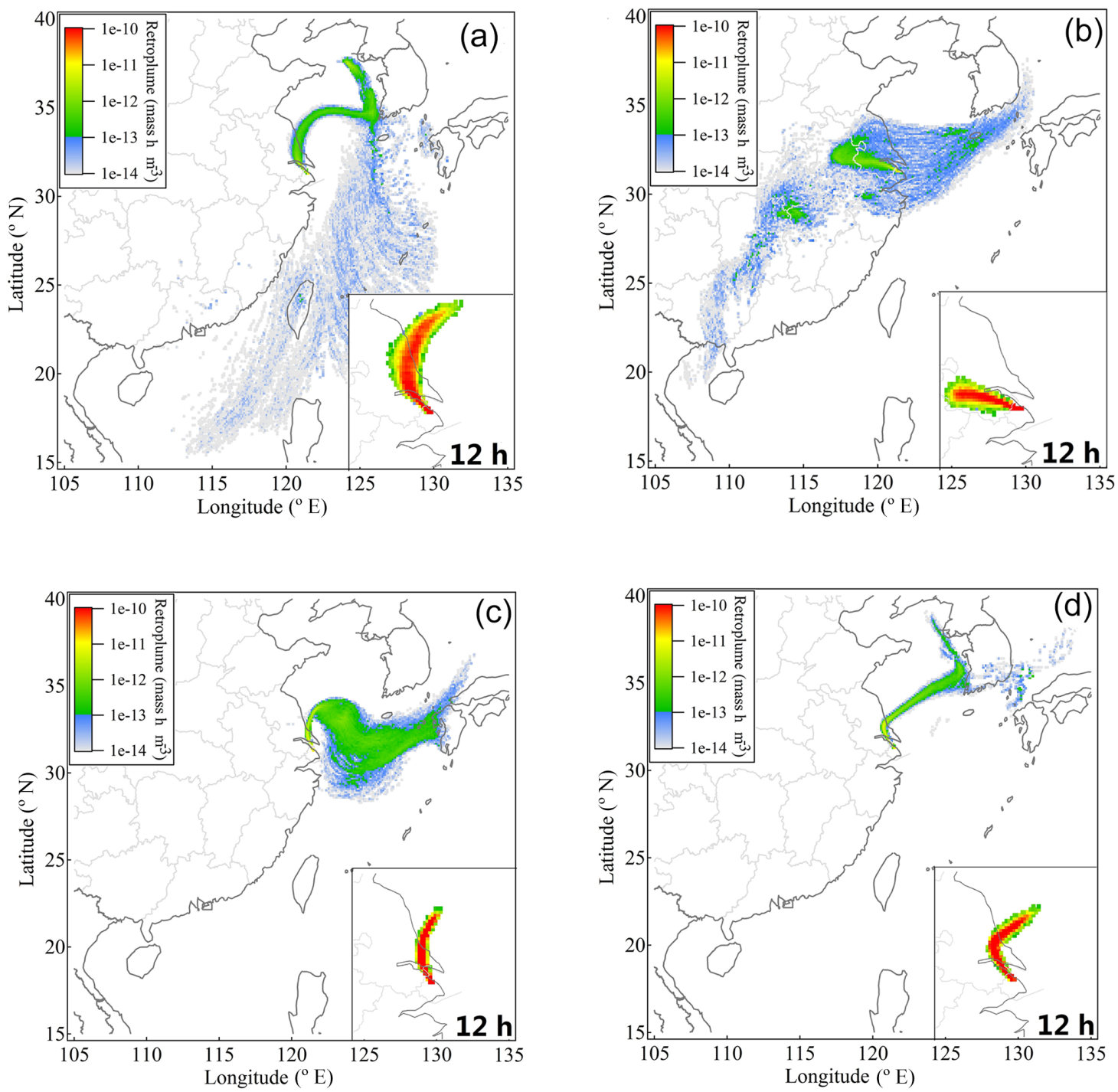

Figure 8. Three-day backward retro-plumes (100 m above the ground level) from the sampling location at (a) 05:00, 12 August 2015; (b) 21:00, 20 August 2015; (c) 06:00, 21 August 2015; and (d) 06:00, 25 August 2015. The embedded boxes show $12 \mathrm{~h}$ backward trajectories.

\subsubsection{Diurnal patterns}

Figure 7 presents the averaged diurnal variations of $\mathrm{C}_{1}$ - and $\mathrm{C}_{2}$-amines and $\mathrm{C}_{3}$ - and $\mathrm{C}_{4}$-amides, together with those of temperature, radiation, and ozone concentration during the campaign. Diurnal patterns for amines and amides with less variation are exhibited in Fig. S9. Mixing ratios of $\mathrm{C}_{1}$ - and $\mathrm{C}_{2}$-amines and $\mathrm{C}_{3}$ - and $\mathrm{C}_{4}$-amides reached their peak values in the early morning (06:00-07:00 LT), and then started to decline as the temperature increased. The mixing ratios were normally the lowest during the day when the temperature rose to the top. The diurnal behavior of amines and amides can be explained by the strong photochemical reactions of these species during the daytime (Barnes et al., 2010; Borduas et al., 2015; Nielsen et al., 2012), especially in summer, as evidenced by the negative correlations between the mixing ratios and radiation (exponential fits with $-0.0002 \leq$ exponents $\leq-0.0001$ ), and between the mixing ratios and ozone (exponential fits with $-0.003 \leq$ exponents $\leq-0.001$ ), a tracer for photochemical activities. Also, nighttime chemistry of amines with $\mathrm{NO}_{3}$ radicals could be active. In summer nighttime of Shanghai, the $\mathrm{NO}_{3}$ radical concentration could be up to $10^{10}$ radicals $\mathrm{cm}^{-3}$ (Wang et al., 2013b) and the reaction rates of amines with $\mathrm{NO}_{3}$ radicals are on the order of $10^{-13} \mathrm{~cm}^{3}$ molecular ${ }^{-1} \mathrm{~s}^{-1}$ (Nielsen et al., 2012). Hence, high mixing ratios of amines at nighttime could be a secondary source of amides through reactions of amines with $\mathrm{NO}_{3}$ radicals.

In addition, an opposite tendency between the mixing ratios and the temperature (exponential fits with $-0.067 \leq \mathrm{ex}$ ponents $\leq-0.049$ ) is clearly evident in our study, which is 
in contrast to the positive temperature dependence of $\mathrm{C}_{3}$ amines and $\mathrm{C}_{6}$-amines in previous studies (Hanson et al., 2011; You et al., 2014; Yu and Lee, 2012). The positive temperature dependencies of $\mathrm{C}_{3}$-amines were explained by deposition of amines onto soil or grass landscapes at night and then partitioning back to the atmosphere in the morning when the surface heats (Hanson et al., 2011; You et al., 2014). On the other hand, land surface in Shanghai is mainly covered by bitumen and cement, on which the behavior of amines might be different.

\subsubsection{Source identification for $\mathrm{C}_{3}$-amides}

A Lagrangian dispersion model has been utilized to further understand the potential sources of $\mathrm{C}_{3}$-amides. This Lagrangian modeling simulation is based on Hybrid Single-Particle Lagrangian Integrated Trajectory (HYSPLIT; Draxler and Hess, 1998; Stein et al., 2015) following the method developed by Ding et al. (2013). Three-day backward retro-plumes (100 $\mathrm{m}$ above the ground level) from the Fudan sampling site are shown for air masses with mixing ratios of $\mathrm{C}_{3}$-amides $>2670$ pptv in Fig. 8, and for air masses with the $\mathrm{C}_{3}$-amide concentration range between $1340 \mathrm{pptv}$ and 2650 pptv in Fig. S10. Especially, in Fig. 8a, the concentration of $\mathrm{C}_{3}$-amides reached $\sim 8700$ pptv. The embedded $12 \mathrm{~h}$ retro-plumes give a better view of the local zones through which the air masses with high concentrations of $\mathrm{C}_{3}$-amides passed before their arrival to the sampling site. Since the atmospheric lifetimes of $N, N$-dimethylformamide (an isomer of $\mathrm{C}_{3}$-amides) and its potential precursor TMA (an isomer of $\mathrm{C}_{3}$-amines) in respect to reactions with $\mathrm{OH}$ radicals are $\sim 3$ and $\sim 10 \mathrm{~h}$, respectively, using a $12 \mathrm{~h}$ average $\mathrm{OH}$ radical concentration of $2 \times 10^{6}$ radicals $\mathrm{cm}^{-3}, \mathrm{C}_{3^{-}}$ amides were likely emitted or formed along the trajectory. As shown in Fig. 8a-d, the air plumes with high concentrations of $\mathrm{C}_{3}$-amides mainly originated from the sea and came from the north of Shanghai. The air mass passed through predominantly industrial areas and cities after landing, and Baoshan industrial zone (one of the main industrial zones in Shanghai) was right on its path during the last $12 \mathrm{~h}$. Therefore, industrial emissions (or other anthropogenic emissions) might be important sources of $\mathrm{C}_{3}$-amides.

Figure S10a-e present another five cases with the next highest concentrations of $\mathrm{C}_{3}$-amides. The air masses primarily came from southwest of the sampling site, and then passed through industrial areas and cities before arrival, including Songjiang and Jinshan industrial zones (another two main industrial zones in Shanghai) during the last $12 \mathrm{~h}$. These results also suggest that industrial emissions or other anthropogenic activities might be important sources of $\mathrm{C}_{3}$-amides.

\section{Conclusions}

This paper presents laboratory characterization of an ethanol HR-ToF-CIMS method for detection of amines and amides, and 1-month field deployment of the ethanol HR-ToF-CIMS in urban Shanghai during summer 2015. Laboratory characterization indicates that our sensitivities for amines were 5.6-19.4 and were $3.8-38.0 \mathrm{~Hz} \mathrm{pptv}^{-1}$ for amides. At $3 \sigma$ of the background signal for a 1 min integration time, the detection limits were $0.10-0.50$ for amines and $0.29-1.95 \mathrm{pptv}$ for amides. Our sensitivities are slightly better than those in previous studies using a similar protonated ethanol-CIMS method (You et al., 2014; Yu and Lee, 2012). Correction of the mass signals of amines and amides is necessary at elevated $\mathrm{RH}$ because of the significant $\mathrm{RH}$ dependence of detection of amines and amides as observed in the laboratory. On the other hand, organics with high proton affinity are unlikely to pose an effect on the detection of amines and amides as along as their concentrations will not lead to reagent ion depletion.

High time resolution, highly sensitive and simultaneous measurements of amines (from a few parts per trillion by volume to hundreds of parts per trillion by volume) and amides (from tens of parts per trillion by volume to a few parts per billion by volume) have been achieved during the ambient campaign. Their diurnal profiles suggest that primary emissions could be important sources of amides in urban Shanghai, in addition to the secondary formation processes, and that photo-oxidation and wet deposition of amines and amides might be their main loss pathway.

A total of 86 nitrogen-containing species including amines and amides were identified with $\mathrm{m} / \mathrm{z}$ less than $163 \mathrm{Th}$, $55.8 \%$ of which are oxygenated. This certainly indicates that the ethanol HR-ToF-CIMS method potentially has a much wider implication in terms of measuring atmospheric nitrogen-containing species. For example, imines (or enamines) and a number of heterocyclic nitrogen-containing compounds (e.g., pyridine and quinoline; see Table S1) were potentially detected by this method.

Nevertheless, the detection of amides in ambient air is consistent with the photochemical chemistry that has been previously studied in the laboratory (Barnes et al., 2010; Borduas et al., 2015; Bunkan et al., 2016; Nielsen et al, 2012). The mixing ratios of amides were significantly higher than those of amines in urban Shanghai during our measurements. Since the newly formed nano-particles are likely highly acidic (Wang et al., 2010a), hydrolysis of amides will give rise to $\mathrm{NH}_{4}^{+}$in the particle, in addition to those formed through direct neutralization between gaseous ammonia and particulate sulfuric acid. Although significant progress on the roles of ammonia and amines in the atmospheric nucleation have been made (Almeida et al., 2013; Kürten et al., 2014) and it has been shown that acetamide can only slightly enhance the nucleation rate of sulfuric acid (Glasoe et al., 2015), the 
exact contribution of amides during atmospheric nucleation and subsequent growth events is yet to be elucidated.

\section{The Supplement related to this article is available online at doi:10.5194/acp-16-14527-2016-supplement.}

Acknowledgements. This study was financially supported by the National Natural Science Foundation of China (no. 21190053, 21222703, 41275142, 21561130150, \& 41575113), the Ministry of Science \& Technology of China (2012YQ220113-4), and the Cyrus Tang Foundation (no. CTF-FD2014001). LW thanks the Royal Society-Newton Advanced Fellowship (NA140106).

Edited by: J. G. Murphy

Reviewed by: three anonymous referees

\section{References}

Almeida, J., Schobesberger, S., Kürten, A., Ortega, I. K., Kupiainen-Määttä, O., Praplan, A. P., Adamov, A., Amorim, A., Bianchi, F., Breitenlechner, M., David, A., Dommen, J., Donahue, N. M., Downard, A., Dunne, E., Duplissy, J., Ehrhart, S., Flagan, R. C., Franchin, A., Guida, R., Hakala, J., Hansel, A., Heinritzi, M., Henschel, H., Jokinen, T., Junninen, H., Kajos, M., Kangasluoma, J., Keskinen, H., Kupc, A., Kurtén, T., Kvashin, A. N., Laaksonen, A., Lehtipalo, K., Leiminger, M., Leppä, J., Loukonen, V., Makhmutov, V., Mathot, S., McGrath, M. J., Nieminen, T., Olenius, T., Onnela, A., Petäjä, T., Riccobono, F., Riipinen, I., Rissanen, M., Rondo, L., Ruuskanen, T., Santos, F. D., Sarnela, N., Schallhart, S., Schnitzhofer, R., Seinfeld, J. H., Simon, M., Sipilä, M., Stozhkov, Y., Stratmann, F., Tome, A., Tröstl, J., Tsagkogeorgas, G., Vaattovaara, P., Viisanen, Y., Virtanen, A., Vrtala, A., Wagner, P. E., Weingartner, E., Wex, H., Williamson, C., Wimmer, D., Ye, P., Yli-Juuti, T., Carslaw, K. S., Kulmala, M., Curtius, J., Baltensperger, U., Worsnop, D. R., Vehkamäki, H., and Kirkby, J.: Molecular understanding of sulphuric acid-amine particle nucleation in the atmosphere, Nature, 502, 359-363, doi:10.1038/nature12663, 2013.

Barnes, I., Solignac, G., Mellouki, A., and Becker, K. H.: Aspects of the Atmospheric Chemistry of Amides, Chem. Phys. Chem., 11, 3844-3857, doi:10.1002/cphc.201000374, 2010.

Barsanti, K. C. and Pankow, J. F.: Thermodynamics of the formation of atmospheric organic particulate matter by accretion reactions - Part 3: Carboxylic and dicarboxylic acids, Atmos. Environ., 40, 6676-6686, doi:10.1016/j.atmosenv.2006.03.013, 2006.

Berndt, T., Stratmann, F., Sipilä, M., Vanhanen, J., Petäjä, T., Mikkilä, J., Grüner, A., Spindler, G., Lee Mauldin III, R., Curtius, J., Kulmala, M., and Heintzenberg, J.: Laboratory study on new particle formation from the reaction $\mathrm{OH}+\mathrm{SO}_{2}$ : influence of experimental conditions, $\mathrm{H}_{2} \mathrm{O}$ vapour, $\mathrm{NH}_{3}$ and the amine tert-butylamine on the overall process, Atmos. Chem. Phys., 10, 7101-7116, doi:10.5194/acp-10-7101-2010, 2010.

Bertram, T. H., Kimmel, J. R., Crisp, T. A., Ryder, O. S., Yatavelli, R. L. N., Thornton, J. A., Cubison, M. J., Gonin, M., and
Worsnop, D. R.: A field-deployable, chemical ionization timeof-flight mass spectrometer, Atmos. Meas. Tech., 4, 1471-1479, doi:10.5194/amt-4-1471-2011, 2011.

Berndt, T., Sipilä, M., Stratmann, F., Petäjä, T., Vanhanen, J., Mikkilä, J., Patokoski, J., Taipale, R., Mauldin III, R. L., and Kulmala, M.: Enhancement of atmospheric $\mathrm{H}_{2} \mathrm{SO}_{4} / \mathrm{H}_{2} \mathrm{O}$ nucleation: organic oxidation products versus amines, Atmos. Chem. Phys., 14, 751-764, doi:10.5194/acp-14-751-2014, 2014.

Borduas, N., da Silva, G., Murphy, J. G., and Abbatt, J. P.: Experimental and theoretical understanding of the gas phase oxidation of atmospheric amides with $\mathrm{OH}$ radicals: kinetics, products, and mechanisms, J. Phys. Chem. A, 119, 4298-4308, doi:10.1021/jp503759f, 2015.

Bunkan, A. J. C., Tang, Y. Z., Sellevag, S. R., and Nielsen, C. J.: Atmospheric Gas Phase Chemistry of $\mathrm{CH}_{2}=\mathrm{NH}$ and $\mathrm{HNC}$, A First-Principles Approach, J. Phys. Chem. A, 118, 5279-5288, doi:10.1021/jp5049088, 2014.

Bunkan, A. J. C., Mikoviny, T., Nielsen, C. J., and Wisthaler, A.: Experimental and theoretical study of the $\mathrm{OH}$-initiated photooxidation of formamide, J. Phys. Chem. A, 120, 1222-1230, doi:10.1021/acs.jpca.6b00032, 2016.

Bzdek, B. R., Ridge, D. P., and Johnston, M. V.: Amine exchange into ammonium bisulfate and ammonium nitrate nuclei, Atmos. Chem. Phys., 10, 3495-3503, doi:10.5194/acp-10-3495-2010, 2010.

Cape, J. N., Cornell, S. E., Jickells, T. D., and Nemitz, E.: Organic nitrogen in the atmosphere - Where does it come from? A review of sources and methods, Atmos. Res., 102, 30-48, doi:10.1016/j.atmosres.2011.07.009, 2011.

Cheng, Y., Li, S., and Leithead, A.: Chemical Characteristics and Origins of Nitrogen-Containing Organic Compounds in $\mathrm{PM}_{2.5}$ Aerosols in the Lower Fraser Valley, Environ. Sci. Technol., 40, 5846-5852, doi:10.1021/es0603857, 2006,

Cornell, S. E., Jickells, T. D., Cape, J. N., Rowland, A. P., and Duce, R. A.:Organics nitrogen deposition on land and coastal environments: a review od methods and data, Atmos. Environ., 37, 2173-2191, doi:10.1016/S1352-2310(03)00133-X, 2003.

Cox, R. A. and Yates, K.: The hydrolyses of benzamides, methylbenzimidatium ions, and lactams in aqueous sulfuric-acid, the excess acidity method in the determination of reactionmechanisms, Can. J. Chem., 59, 2853-2863, doi:10.1139/V81414, 1981.

Dawson, M. L., Perraud, V., Gomez, A., Arquero, K. D., Ezell, M. J., and Finlayson-Pitts, B. J.: Measurement of gas-phase ammonia and amines in air by collection onto an ion exchange resin and analysis by ion chromatography, Atmos. Meas. Tech., 7, 27332744, doi:10.5194/amt-7-2733-2014, 2014.

Ding, A. J., Wang, T., and Fu, C. B.: Transport characteristics and origins of carbon monoxide and ozone in Hong Kong, South China, J. Geophys. Res.-Atmos., 118, 9475-9488, doi:10.1002/jgrd.50714, 2013.

Draxler, R. R. and Hess, G. D.: An overview of the HYSPLIT_4 modeling system of trajectories, dispersion, and deposition, Aust. Meteor. Mag., 47, 295-308,1998.

El Dib, G. and Chakir, A.: Temperature-dependence study of the gas-phase reactions of atmospheric NO3 radicals with a series of amides, Atmos. Environ., 41, 5887-5896, doi:10.1016/j.atmosenv.2007.03.038, 2007. 
Erupe, M. E., Viggiano, A. A., and Lee, S.-H.: The effect of trimethylamine on atmospheric nucleation involving $\mathrm{H}_{2} \mathrm{SO}_{4}$, Atmos. Chem. Phys., 11, 4767-4775, doi:10.5194/acp-11-47672011, 2011.

Finlayson-Pitts, B. J. and Pitts, J. N.: Chemistry of the upper and lower atmosphere : theory, experiments, and applications, Academic Press, San Diego, 969 pp., 2000.

Freshour, N. A., Carlson, K. K., Melka, Y. A., Hinz, S., Panta, B., and Hanson, D. R.: Amine permeation sources characterized with acid neutralization and sensitivities of an amine mass spectrometer, Atmos. Meas. Tech., 7, 3611-3621, doi:10.5194/amt7-3611-2014, 2014.

Ge, X., Wexler, A. S., and Clegg, S. L.: Atmospheric amines - Part I, A review, Atmos. Environ., 45, 524-546, doi:10.1016/j.atmosenv.2010.10.012, 2011.

Glasoe, W. A., Volz, K., Panta, B., Freshour, N., Bachman, R., Hanson, D. R., McMurry, P. H., and Jen, C.: Sulfuric acid nucleation: an experimental study of the effect of seven bases, J. Geophys. Res.-Atmos., 120, 1933-1950, doi:10.1002/2014JD022730, 2015.

Hanson, D. R., McMurry, P. H., Jiang, J., Tanner, D., and Huey, L. G.: Ambient Pressure Proton Transfer Mass Spectrometry: Detection of Amines and Ammonia, Environ. Sci. Technol., 45, 8881-8888, doi:10.1021/es201819a, 2011.

Hellén, H., Kieloaho, A. J., and Hakola, H.: Gas-phase alkyl amines in urban air; comparison with a boreal forest site and importance for local atmospheric chemistry, Atmos. Environ., 94, 192-197, doi:10.1016/j.atmosenv.2014.05.029, 2014.

Kieloaho, A.-J., Hellén, H., Hakola, H., Manninen, H. E., Nieminen, T., Kulmala, M., and Pihlatie, M.: Gas-phase alkylamines in a boreal Scots pine forest air, Atmos. Environ., 80, 369-377, doi:10.1016/j.atmosenv.2013.08.019, 2013.

Kim, H. A., Kim, K., Heo, Y., Lee, S. H., and Choi, H. C.: Biological monitoring of workers exposed to N,N-dimethylformamide in synthetic leather manufacturing factories in Korea, Int. Arch. Occup. Environ. Health, 77, 108-112, doi:10.1007/s00420-0030474-1, 2004.

Kuhn, U., Sintermann, J., Spirig, C., Jocher, M., Ammann, C., and Neftel, A.: Basic biogenic aerosol precursors: Agricultural source attribution of volatile amines revised, Geophys. Res. Lett., 38, L16811, doi:10.1029/2011GL047958, 2011.

Kupiainen, O., Ortega, I. K., Kurtén, T., and Vehkamäki, H.: Amine substitution into sulfuric acid - ammonia clusters, Atmos. Chem. Phys., 12, 3591-3599, doi:10.5194/acp-12-3591-2012, 2012.

Kürten, A., Jokinen, T., Simon, M., Sipilä, M., Sarnela, N., Junninen, H., Adamov, A., Almeida, J., Amorim, A., Bianchi, F., Breitenlechner, M., Dommen, J., Donahue, N. M., Duplissy, J., Ehrhart, S., Flagan, R. C., Franchin, A., Hakala, J., Hansel, A., Heinritzi, M., Hutterli, M., Kangasluoma, J., Kirkby, J., Laaksonen, A., Lehtipalo, K., Leiminger, M., Makhmutov, V., Mathot, S., Onnela, A., Petäjä, T., Praplan, A. P., Riccobono, F., Rissanen, M. P., Rondo, L., Schobesberger, S., Seinfeld, J. H., Steiner, G., Tomé, A., Tröstl, J., Winkler, P. M., Williamson, C., Wimmer, D., Ye, P., Baltensperger, U., Carslaw, K. S., Kulmala, M., Worsnop, D. R., and Curtius, J.: Neutral molecular cluster formation of sulfuric acid-dimethylamine observed in real time under atmospheric conditions, P. Natl. Acad. Sci. USA, 111, 1501915024, doi:10.1073/pnas.1404853111, 2014.
Kürten, A., Bergen, A., Heinritzi, M., Leiminger, M., Lorenz, V., Piel, F., Simon, M., Sitals, R., Wagner, A. C., and Curtius, J.: Observation of new particle formation and measurement of sulfuric acid, ammonia, amines and highly oxidized organic molecules at a rural site in central Germany, Atmos. Chem. Phys., 16, 1279312813, doi:10.5194/acp-16-12793-2016, 2016.

Kurtén, T., Loukonen, V., Vehkamäki, H., and Kulmala, M.: Amines are likely to enhance neutral and ion-induced sulfuric acid-water nucleation in the atmosphere more effectively than ammonia, Atmos. Chem. Phys., 8, 4095-4103, doi:10.5194/acp-8-4095-2008, 2008.

Laskin, A., Smith, J. S., and Laskin, J.: Molecular characterization of nitrogen-containing organic compounds in biomass burning aerosols using high-resolution mass spectrometry, Environ. Sci. Technol., 43, 3764-3771, doi:10.1021/es803456n, 2009.

Leach, J., Blanch, A., and Bianchi, A. C.: Volatile organic compounds in an urban airborne environment adjacent to a municipal incinerator, waste collection centre and sewage treatment plant, Atmos. Environ., 33, 4309-4325, doi:10.1016/S13522310(99)00115-6, 1999.

Lee, A., Goldstein, A. H., Kroll, J. H., Ng, N. L., Varutbangkul, V., Flagan, R. C., and Seinfeld, J. H.: Gas-phase products and secondary aerosol yields from the photooxidation of 16 different terpenes, J. Geophys. Res.-Atmos., 111, D17305, doi:10.1029/2006jd007050, 2006.

Lee, D. and Wexler, A. S.: Atmospheric amines - Part III: Photochemistry and toxicity, Atmos. Environ., 71, 95-103, doi:10.1016/j.atmosenv.2013.01.058, 2013.

Lopez-Hilfiker, F. D., Mohr, C., Ehn, M., Rubach, F., Kleist, E., Wildt, J., Mentel, Th. F., Lutz, A., Hallquist, M., Worsnop, D., and Thornton, J. A.: A novel method for online analysis of gas and particle composition: description and evaluation of a Filter Inlet for Gases and AEROsols (FIGAERO), Atmos. Meas. Tech., 7, 983-1001, doi:10.5194/amt-7-983-2014, 2014.

Ma, Y., Xu, X., Song, W., Geng, F., and Wang, L.: Seasonal and diurnal variations of particulate organosulfates in urban Shanghai, China, Atmos. Environ., 85, 152-160, doi:10.1016/j.atmosenv.2013.12.017, 2014.

Malloy, Q. G. J., Li Qi, Warren, B., Cocker III, D. R., Erupe, M. E., and Silva, P. J.: Secondary organic aerosol formation from primary aliphatic amines with $\mathrm{NO}_{3}$ radical, Atmos. Chem. Phys., 9, 2051-2060, doi:10.5194/acp-9-2051-2009, 2009.

Murphy, S. M., Sorooshian, A., Kroll, J. H., Ng, N. L., Chhabra, P., Tong, C., Surratt, J. D., Knipping, E., Flagan, R. C., and Seinfeld, J. H.: Secondary aerosol formation from atmospheric reactions of aliphatic amines, Atmos. Chem. Phys., 7, 2313-2337, doi:10.5194/acp-7-2313-2007, 2007.

Nielsen, C. J., D’Anna, B., Karl, M., Aursnes, M., Boreave, A.,Bossi, R., Bunkan, A. J. C., Glasius, M., Hallquist, M., Hansen,A.-M. K., Kristensen, K., Mikoviny, T., Maguta, M. M., Müller,M., Nguyen, Q., Westerlund, J., Salo, K., Skov, H., Stenstrøm, Y., and Wisthaler, A.: Atmospheric Degradation of Amines (ADA), Norwegian Institute for Air Research, Kjeller, Norway, 2011.

Nielsen, C. J., Herrmann, H., and Weller, C.: Atmospheric chemistry and environmental impact of the use of amines in carbon capture and storage (CCS), Chem. Soc. Rev., 41, 6684-6704, doi:10.1039/c2cs35059a, 2012. 
NIST: NIST Standard Reference Database Number 69, edited, National Institute for Standard Technology (NIST) Chemistry Web Book, available at: http://webbook.nist.gov/chemistry/, last access: 23 May 2016.

Nowak, J. B., Huey, L. G., Eisele, F. L., Tanner, D., Mauldin III, R. L., Cantrell, C. A., Kosciuch, E., and Davis, D.: Chemical ionization mass spectrometry technique for detection of dimethylsulfoxide and ammonia, J. Geophys. Res.-Atmos., 107, doi:10.1029/2001jd001058, 2002.

Qiu, C., Wang, L., Lal, V., Khalizov, A. F., and Zhang, R.: Heterogeneous reactions of alkylamines with ammonium sulfate and ammonium bisulfate, Environ. Sci. Technol., 45, 4748-4755, doi:10.1021/es1043112, 2011.

Roberts, J. M., Veres, P. R., Cochran, A. K., Warneke, C., Burling, I. R., Yokelson, R. J., Lerner, B., Gilman, J. B., Kuster, W. C., Fall, R., and de Gouw, J.: Isocyanic acid in the atmosphere and its possible link to smoke-related health effects, P. Natl. Acad. Sci. USA, 108, 8966-8971, doi:10.1073/pnas.1103352108, 2011.

Rogge, W. F., Hildemann, L. M., Mazurek, M. A., Cass, G. R., and Simonelt, B. R. T.: Sources Of Fine Organic Aerosol, 1. Charbroilers And Meat Cooking Operations, Environ. Sci. Technol., 25, 1112-1125, doi:10.1021/Es00018a015, 1991.

Schmeltz, I. and Hoffmann, D.: Nitrogen-Containing Compounds In Tobacco And Tobacco-Smoke, Chem. Rev., 77, 295-311, doi:10.1021/Cr60307a001, 1977.

Sellegri, K., Hanke, M., Umann, B., Arnold, F., and Kulmala, M.: Measurements of organic gases during aerosol formation events in the boreal forest atmosphere during QUEST, Atmos. Chem. Phys., 5, 373-384, doi:10.5194/acp-5-373-2005, 2005.

Smith, D. F., Kleindienst, T. E., and McIver, C. D.: Primary product

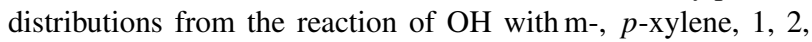
4- and 1, 3, 5-trimethylbenzene, J. Atmos. Chem., 34, 339-364, doi:10.1023/A:1006277328628, 1999.

Simon, M., Heinritzi, M., Herzog, S., Leiminger, M., Bianchi, F., Praplan, A., Dommen, J., Curtius, J., and Kürten, A.: Detection of dimethylamine in the low pptv range using nitrate chemical ionization atmospheric pressure interface time-of-flight (CI-APiTOF) mass spectrometry, Atmos. Meas. Tech., 9, 2135-2145, doi:10.5194/amt-9-2135-2016, 2016.

Smith, J. N., Barsanti, K. C., Friedli, H. R., Ehn, M., Kulmala, M., Collins, D. R., Scheckman, J. H., Williams, B. J., and McMurry, P. H.: Observations of aminium salts in atmospheric nanoparticles and possible climatic implications, P. Natl. Acad. Sci. USA, 107, 6634-6639, doi:10.1073/pnas.0912127107, 2010.

Sipilä, M., Sarnela, N., Jokinen, T., Junninen, H., Hakala, J., Rissanen, M. P., Praplan, A., Simon, M., Kürten, A., Bianchi, F., Dommen, J., Curtius, J., Petäjä, T., and Worsnop, D. R.: Bisulfate - cluster based atmospheric pressure chemical ionization mass spectrometer for high-sensitivity $(<100 \mathrm{ppqV})$ detection of atmospheric dimethyl amine: proof-of-concept and first ambient data from boreal forest, Atmos. Meas. Tech., 8, 4001-4011, doi:10.5194/amt-8-4001-2015, 2015.

Stein, A. F., Draxler, R. R, Rolph, G. D., Stunder, B. J. B., Cohen, M. D., and Ngan, F.: NOAA's HYSPLIT atmospheric transport and dispersion modeling system, B. Am. Meteorol. Soc., 96, 2059-2077, doi:10.1175/BAMS-D-14-001, 2015.

VandenBoer, T. C., Petroff, A., Markovic, M. Z., and Murphy, J. G.: Size distribution of alkyl amines in continental particulate matter and their online detection in the gas and particle phase,
Atmos. Chem. Phys., 11, 4319-4332, doi:10.5194/acp-11-43192011, 2011.

Wang, L., Khalizov, A. F., Zheng, J., Xu, W., Ma, Y., Lal, V., and Zhang, R.: Atmospheric nanoparticles formed from heterogeneous reactions of organics, Nat. Geosci., 3, 238-242, doi:10.1038/ngeo778, 2010a.

Wang, L., Lal, V., Khalizov, A. F., and Zhang, R. Y.: Heterogeneous Chemistry of Alkylamines with Sulfuric Acid: Implications for Atmospheric Formation of Alkylaminium Sulfates, Environ. Sci. Technol., 44, 2461-2465, doi:10.1021/es9036868, 2010b.

Wang, L., Du, H., Chen, J., Zhang, M., Huang, X., Tan, H., Kong, L., and Geng, F.: Consecutive transport of anthropogenic air masses and dust storm plume: Two case events at Shanghai, China, Atmos. Res., 127, 22-33, doi:10.1016/j.atmosres.2013.02.011, 2013a.

Wang, S., Shi, C., Zhou, B., Zhao, H., Wang, Z., Yang, S., and Chen, L.: Observation of NO3 radicals over Shanghai, China, Atmos. Environ., 70, 401-409, doi:10.1016/j.atmosenv.2013.01.022, 2013b.

Wang, X. K., Rossignol, S., Ma, Y., Yao, L., Wang, M. Y., Chen, J. M., George, C., and Wang, L.: Molecular characterization of atmospheric particulate organosulfates in three megacities at the middle and lower reaches of the Yangtze River, Atmos. Chem. Phys., 16, 2285-2298, doi:10.5194/acp-16-2285-2016, 2016.

Xiao, S., Wang, M. Y., Yao, L., Kulmala, M., Zhou, B., Yang, X., Chen, J. M., Wang, D. F., Fu, Q. Y., Worsnop, D. R., and Wang, L.: Strong atmospheric new particle formation in winter in urban Shanghai, China, Atmos. Chem. Phys., 15, 1769-1781, doi:10.5194/acp-15-1769-2015, 2015.

You, Y., Kanawade, V. P., de Gouw, J. A., Guenther, A. B., Madronich, S., Sierra-Hernández, M. R., Lawler, M., Smith, J. N., Takahama, S., Ruggeri, G., Koss, A., Olson, K., Baumann, K., Weber, R. J., Nenes, A., Guo, H., Edgerton, E. S., Porcelli, L., Brune, W. H., Goldstein, A. H., and Lee, S.-H.: Atmospheric amines and ammonia measured with a chemical ionization mass spectrometer (CIMS), Atmos. Chem. Phys., 14, 12181-12194, doi:10.5194/acp-14-12181-2014, 2014.

Yu, H. and Lee, S.-H.: Chemical ionisation mass spectrometry for the measurement of atmospheric amines, Environ. Chem., 9, 190, doi:10.1071/en12020, 2012.

Yu, H., McGraw, R., and Lee, S. H.: Effects of amines on formation of sub-3 nm particles and their subsequent growth, Geophys. Res. Lett., 39, L02807, doi:10.1029/2011g1050099, 2012.

Zhang, R., Khalizov, A., Wang, L., Hu, M., and Xu, W.: Nucleation and growth of nanoparticles in the atmosphere, Chem. Rev., 112, 1957-2011, doi:10.1021/cr2001756, 2012.

Zheng, J., Ma, Y., Chen, M., Zhang, Q., Wang, L., Khalizov, A. F., Yao, L., Wang, Z., Wang, X., and Chen, L.: Measurement of atmospheric amines and ammonia using the high resolution timeof-flight chemical ionization mass spectrometry, Atmos. Environ., 102, 249-259, doi:10.1016/j.atmosenv.2014.12.002, 2015.

Zhu, L., Schade, G. W., and Nielsen, C. J.: Real-time monitoring of emissions from monoethanolamine-based industrial scale carbon capture facilities, Environ. Sci. Technol., 47, 14306-14314, doi:10.1021/es4035045, 2013. 